\title{
The Quality of Government
}

\author{
Rafael La Porta \\ Harvard University and NBER \\ Florencio Lopez-de-Silanes \\ Harvard University and NBER \\ Andrei Shleifer \\ Harvard University and NBER \\ Robert Vishny \\ University of Chicago and NBER
}

We investigate empirically the determinants of the quality of governments in a large cross-section of countries. We assess government performance using measures of government intervention, public sector efficiency, public good provision, size of government, and political freedom. We find that countries that are poor, close to the equator, ethnolinguistically heterogeneous, use French or socialist laws, or have high proportions of Catholics or Muslims exhibit inferior government performance. We also find that the larger governments tend to be the better performing ones. The importance of (reasonably) exogenous historical factors in explaining the variation in government performance across countries sheds light on the economic, political, and cultural theories of institutions.

\section{Introduction and Overview}

In recent years economists have stressed the idea that good economic institutions, particularly those in the public sector, are instrumental to economic growth. Some of such institutions include limited government, a relatively benign and uncorrupt bureaucracy, a legal system that protects property rights and enforces contracts, and modest taxation and regulation. Good government has been shown to contribute to the economic development of European countries over the last millennium (North, 1981; De Long and Shleifer, 1993), to growth across countries over the last 40 years (Knack and Keefer, 1995; Mauro, 1995; Easterly and Levine, 1997), and to the successful transition from socialism to capitalism (Weingast, 1995; Johnson, Kaufmann, and Shleifer, 1997). The im-

The authors are extremely grateful to Alberto Alesina, Robert Barro, Olivier Blanchard, Colin Camerer, Brad DeLong, Edward Glaeser, Claudia Goldin, Simon Johnson, Lawrence Katz, David Laibson, David Landes, Daniel Treisman, and Lynn Zucker for discussions of this article, and to Tatyana Nenova for research assistance.

(C) 1999 Oxford University Press 
portance of good government for growth thus appears to be a well-established empirical proposition.

This proposition raises an obvious question: How did some countries come to have good government and others did not? How does history influence government performance? In this article we address these questions using data on government performance and its possible determinants for a large sample of countries. We present, and evaluate empirically, a number of theories that focus on economic, political, and cultural determinants of government performance.

As a first step, it is important to agree on what constitutes "good government." We use the term "good" in this article to stand for good-for-economicdevelopment. One can alternatively consider good government performance to manifest itself in lower inequality, greater diversity among people, or maintained traditions, but here we keep the narrow view. Even in this narrow view, however, there are many distinct dimensions of good government performance. Following Montesquieu (1748) and Smith (1776), economists have focused on the security of property rights-lack of intervention by the government, benign regulation, low taxation-as the crucial metric of good performance. Other signs of well-functioning government include high quality of the bureaucracy, successful provision of essential public goods, effective spending, and democracy - which is both an end in itself and a mechanism for modifying institutions. In this article we examine all these separate dimensions of the quality of government.

The theories of determinants of institutional-and more specifically government-performance fall into three broad categories: economic, political, and cultural. We treat these groups of theories as sharply distinct, even though their advocates would surely accuse us of caricaturing their views. Economic theories (Demsetz, 1967; North, 1981) hold that institutions are created when it is efficient to create them, that is, when the social benefits of building institutions exceed the transaction costs of doing so. Thus private property rights over land are created when land becomes scarce, and when the costs of enforcing such rights fall below the benefits. Political theories (Marx, 1872; North, 1990; Olson, 1993), in contrast, focus on redistribution rather than efficiency, and hold that policies and institutions are shaped by those in power to stay in power and to transfer resources to themselves. For Marx, the interests in power are identified with "class," but they can also be autocrats, autonomous bureaucracies, organized religion, ethnic groups, or even particular organized economic interests (the nobility, state enterprises, or even retirees). According to political theories, government policies are inefficient not because they are expensive to fix, but because their creators want them so. Finally, according to cultural theories (Banfield, 1958; Weber, 1958; Putnam, 1993; Landes, 1998), societies hold beliefs that shape collective action and government. Some societies are so intolerant or distrustful that their governments simply cannot function effectively.

To evaluate the ability of the different theories to explain the variation in government performance across countries we need to find (reasonably) exogenous 
sources of variation in the economic, political, and cultural characteristics of these countries. Begin with economic theories. Perhaps the most direct implication of these theories is that as the scale of economic activity expands, better institutions become affordable, and hence government performance should improve (North, 1981). Of course, better government in turn improves economic performance, so the scale of economic activity is endogenous. It turns out to be true that richer countries have better government, but this is hardly the whole story.

With political and cultural theories we have better exogenous measures of country characteristics. We use two strategies for evaluating political theories, the essence of which we take to be that political divergence in society - between social, ethnic, class, or other interests-is detrimental to government performance. One strategy is to look at ethnic heterogeneity in a country, which several recent studies have identified as an important exogenous measure of redistributive tendencies (Alesina, Baqir, and Easterly, 1999; Easterly and Levine, 1997). Another strategy is to look at the legal systems, which can be viewed as indicators of the relative power of the State vis-à-vis property owners. In particular, common law has developed in England to some extent as a defense of Parliament and property owners against the attempts by the sovereign to regulate and expropriate them. Civil law, in contrast, has developed more as an instrument used by the sovereign for State building and controlling economic life. Finally, socialist law is the expression of ultimate control of the economy by the State. We consider a country's legal system as a potential determinant of government performance. In this article we do not use standard political variables - parliamentary versus presidential system, fragmentation of the parliament, democracy versus dictatorship—as independent determinants of government performance because, from our perspective, these variables are largely endogenous.

To examine cultural theories, we follow a variety of authors, from Weber to Landes, who use religion as a proxy for work ethic, tolerance, trust, and other characteristics of society that may be instrumental in shaping its government. We look at the religious affiliations of the population as the potential cultural determinants of performance, and in particular focus on the Catholic and Muslim religions which have been recently singled out by Landes (1998) as hostile to institutional development.

Our data show a strong positive association between per capita income and government performance, but they also suggest that economic theories of institutions are not the whole story. To a significant extent, government performance is determined by political, and perhaps also cultural, factors. We find that ethnolinguistic heterogeneity and the use of a more interventionist legal system, such as socialist or French civil law, predict inferior government performance. So do significant shares of Catholics or Muslims in the population. The influence of religion on government performance has a number of political, as well as cultural, interpretations.

In the next section we spell out the different theories and their potentially testable predictions. In Section 3 we describe our data and empirical strategy. 
In section 4 we present the main results bearing on the alternative theories. Section 5 concludes.

\section{Theories of Institutional Development}

\subsection{Measuring Government Performance}

The government shapes the economic life of a country in a variety of ways: protecting or grabbing property, allowing or suppressing dissent, serving or abusing the public through its agents. To begin understanding what explains the variation in government performance across countries, our first step is to describe some of the dimensions of such performance.

Perhaps the most standard view is that a good government protects property rights, and keeps regulations and taxes light; that is, a good government is relatively noninterventionist (Smith, 1776; North, 1981; Knack and Keefer, 1995). Our first group of measures, therefore, focuses on interventionism, and specifically on the quality of regulation and the security of property rights. One area where the interpretation of interventionism is ambiguous is taxation. In one view, high taxation is a measure of high intervention. In another view, high tax rates are imposed with the consent of the governed to finance sought-after public goods, whereas low taxes are all that a deeply interventionist government can hope to collect. Recent interpretations of higher taxes in Britain than in France in the 18th century (Brewer, 1988; Finer, 1997), as well as the evidence on transition from socialism (Johnson, Kaufmann, and Shleifer, 1997), are consistent with the notion that higher tax rates may go hand in hand with better institutions.

Noninterventionism is only one aspect of good government. A further important, and separate, dimension can be described as the efficiency of government, or the quality of the bureaucracy (Rauch, 1995; Rauch and Evans, 1997). When a government intervenes, it can do so reasonably efficiently, or with delays, corruption, and other distortions (Mauro, 1995; Treisman, 1997). When a government taxes, it can do so with relatively high compliance, or with low compliance, which often leads to corruption and arbitrary variation of effective tax rates across similarly situated taxpayers. On average, greater interventionism should be associated with lower efficiency, since entrusting officials with greater regulatory and taxing powers invites corruption and bureaucratic delay (Shleifer and Vishny, 1993). Nonetheless, some bureaucracies deliver a given bundle of interventions more efficiently than others. There are many examples indicating that interventionism and efficiency are not just mirror images of each other. The government in 18th-century Britain was efficient by the standards of the day and (outside of taxation) relatively noninterventionist, whereas the government of Frederick the Great of Prussia was also efficient, but highly interventionist (Johnson, 1975; Ertman, 1997). The Giolitti government in Italy before World War I was highly corrupt and inefficient, but relatively noninterventionist; under Mussolini, the government became much more interventionist while keeping its low efficiency levels; under Christian Democrats

after World War II, interventionism was reduced while the efficiency levels were maintained (Mack Smith, 1997). In theory, it may help development for a 
highly interventionist government to be inefficient (Huntington, 1968). In any event, interventionism and efficiency are in part distinct aspects of government performance.

In addition to controlling, taxing, regulating, and charging bribes, governments in many countries actually provide public services that are essential for economic development. Government performance of a given country should be assessed in part by evaluating the quality of public good provisions such as schooling, infant mortality, literacy, and infrastructure. While some of these goods are in part provided privately, governments have come to play a large role in delivering health, education, and infrastructure. High quality of these goods, as opposed to just high expenditures, is a sign of a well-functioning government.

A more problematic, but nonetheless important, indicator of performance is government expenditures on transfers, its own consumption, and public sector employment. High government expenditures in these areas may reflect the citizens' willingness to pay taxes because they like what the government does, and as such reflect good government. Alternatively, high expenditures on transfers and subsidies or on government consumption may reflect high levels of distortionary taxes and redistribution (Barro, 1991), and hence represent a failure to protect the public from state intervention. Some measures of the size of government, such as the size of the state-owned enterprise sector and the relative size of public sector employment (Shleifer and Vishny, 1994, 1998), are perhaps more indicative of political and redistributive, rather than public-spirited, intent. Examining the determinants of these types of government spending may thus help us distinguish alternative theories of institutions.

A final dimension of good government which we examine is democracy and political rights. We look at this both because political freedom is a crucial element of good government and because economic freedom generally goes together with political freedom (Hayek, 1944). The relationship between democracy and economic success has been difficult to find in recent data (Barro, 1996b), although over the longer span of history more limited governments have presided over more successful development (DeLong and Shleifer, 1993).

\subsection{Theories of Institutions}

Economists, historians, sociologists, and political scientists have developed a large number of theories of institutional development. Unfortunately, scholars often pursue their own theories without paying too much attention to the alternatives. This is true, for example, of Marx (1872), Weber (1958), Demsetz (1967), North (1981, 1990), Putnam (1993), Fukuyama (1995), and Landes (1998). Our goal is to provide some evidence that illuminates, and perhaps can distinguish, alternative theories of institutions and their implications for government performance. To this end we first organize these theories (without presenting any new ones) and then present their possibly testable implications.

We divide the available theories into three broad categories: economic, political, and cultural. These theories focus on different reasons why institutions look the way they do: social efficiency needs in the case of economic theories, 
redistribution toward powerful groups in the case of political theories, and social beliefs in the case of cultural theories. Yet all these theories are consistent with economics more broadly in the sense that political actors pursue their selfish objectives in light of their beliefs. Even so, this division is probably too crude, and the writers we examined-most notably North—typically have economic, political and cultural elements to their stories.

Economic theories of institutions suggest that they are created whenever the social benefits of doing so exceed the costs (Demsetz, 1967; North, 1981). ${ }^{1}$ For example, a government protects private property when the returns to such protection exceed the cost of police. This theory generally takes the view that institutions are efficient, and that the trouble is the absence of institutions, rather than the existence of bad ones. Even if this theory is an important part of reality, it is at best incomplete-we see too many extractive and inefficient governments around (Bates, 1981; Olson, 1996; Finer, 1997; Shleifer and Vishny, 1998).

A second group of theories of institutions is political; they state, roughly, that institutions and policies are shaped by those in power to stay in power and to amass resources. Government policies are used to control assets, including people, and to convert this control into wealth. ${ }^{2}$ To Marx, societies are divided into social classes, and policies are designed by the ruling class. Modern theories are more nuanced and allow redistributive policies to be shaped by sovereigns, bureaucracies, ethnic groups, religions, or even particular lobbies. Thus the Mandarin bureaucracy shaped the Chinese government for its own and the emperor's benefit for hundreds of years, and the Communist bureaucracy in the USSR did the same during Soviet rule. What political theories have in common is the idea that, when some group in a society becomes powerful enough, it shapes policies to its own rather than social advantage. ${ }^{3}$

Perhaps the best illustrations of political theory come from the history of sovereign state-building, which has been magnificently recounted by Finer (1997). Finer shows, for example, how the Russian czars, Ottoman sultans, and Tokugawa shoguns created polities in which they had absolute unchecked power through near complete control over the military, the aristocracy, the religion, and the bureaucracy [see also Pipes (1974), Jones (1981), and Tilly (1990)]. These empires were short on property rights, long on government intervention, and (eventually) quite short on government efficiency as well; they had few laws or civil rights and relatively small governments. These qualities

1. Following Olson (1965), these theories pay a great deal of attention to free-rider problems that need to be overcome to produce any public goods, including institutions. This is where the cultural theory typically enters: ideology or beliefs help overcome free-riding.

2. Analytically we can analyze the political theories of institutions in terms of the control rights of various agents (Grossman and Hart, 1986; Boycko, Shleifer, and Vishny, 1995, 1996).

3. Governments become massively redistributive when there are relatively few very powerful groups with different interests, not when there are many relatively weak groups each pushing in its own direction. This view is consistent with Becker's (1983) notion that interactions of many relatively small lobbies lead to efficient outcomes and is inconsistent with Olson's (1982) view that increased density of such lobbies reduces efficiency through political stalemate. Having lots of weak articulated interests is better than having a few very strong ones. 
of government were an immediate consequence of the intent of the political rulers to maintain complete control over their subjects.

Finer (1997) contrasts this oriental despotism with European absolutism, where the power of the monarch was at least partially checked by law, and where the Church (in Catholic countries) and the aristocracy to some extent restricted autocratic control. These countries, as a consequence, had more secure property rights, and greater political rights of the subjects, although the sovereigns continually tried to restrict these rights to enhance their revenues. Civil law developed in Western Europe as part of such restrained control by the sovereigns over their subjects. Consistent with the point that government efficiency is a separate matter than intervention, some European countries, such as Prussia, managed to create relatively efficient bureaucracies, while others, such as Italy and France, have created "patrimonial" bureaucracies that used their powers to pursue the personal interests of the officials rather than those of the sovereign (Ertman 1997).

Finally, in contrast to European absolutism, British government was shaped by the victory of aristocracy over the crown, and resulted in a more limited government, greater political freedoms, and a more efficient bureaucracy. Common law was developed, in part, as a mechanism for protecting the subjects from the crown. Perhaps surprisingly, the consent of the governed enabled the British Parliament to raise considerably higher tax revenues for military spending than the French kings could ever raise (Brewer, 1988): the British government was bigger though less interventionist. ${ }^{4}$ Whatever the nuances of these histories, the basic point that institutions and policies are shaped not by considerations of efficiency but rather by the ability of the various players to extract rents seems to be broadly confirmed by the narrative accounts of world history [see also Jones (1981), DeLong and Shleifer (1993), Ertman (1997), Kamen (1997), etc.].

In some cases, political and economic theories of institutions share similar predictions. For example, it may serve the interest of tax-extracting sovereigns to impose some constraints on their own powers so as to "fatten" the goose before roasting it, or even to provide public goods such as justice and property rights protection to enhance tax revenues (North, 1981; Olson, 1993). In those cases, even though the ultimate goal of a policy is redistribution toward the sovereign through enhanced tax collections, its immediate effect is to increase efficiency. Frederick the Great's reforms are a great example of this phenomenon (Johnson, 1975). Although kings are surely different from outright plunderers, the economic and political theories differ in that the former, in the first instance, do not accommodate purely rent-seeking policies. Unlike economic theories, political theories readily predict the existence of inefficient, interventionist, and distortionary policies that are put in place not because they raise the social product but because they redistribute it. Such clearly redistributive policies render political and economic theories distinguishable at least in principle.

4. This contrasts with the very limited aristocratic government of Poland, where the barons occasionally could not agree to pay for armies needed to resist aggression, with the result that the government was small and the country got even smaller (Ertman, 1997; Finer, 1997). 
Finally, cultural theories state that some societies form beliefs and ideas that are conducive to good government, while others do not (see Weber, 1958). Some of these beliefs and ideas are nonverifiable (e.g., beliefs in punishments are rewards after death), others verifiable and false (e.g., certain racists and anti-Semitic beliefs), and still others self-fulfilling (e.g., the belief that your neighbors do not cooperate in any collective action and so you should not either). When these beliefs are highly pervasive and persistent, they get to be called "culture."

Two recent instantly famous versions of such cultural theories are due to Robert Putnam (1993) and David Landes (1998). Putnam's theory [see also Coleman (1990) and Fukuyama (1995)] states that trust in strangers facilitates collective action, which he views as essential for the provision of public goods. Putnam comments that in Italy the Catholic Church had adverse effects on trust, because "vertical bonds of authority are more characteristic of the Italian Church than horizontal bonds of fellowship" (p. 107). Putnam compares a variety of social outcomes in high-trust northern Italy and low-trust southern Italy, and finds confirmation of his views. Knack and Keefer (1997) and La Porta et al. (1997b) also find empirical support for the view that higher trust in strangers predicts better government performance, even across countries.

More recently, Landes (1998) argued that during the period of economic takeoff of Protestant countries, Catholic and Muslim countries in particular have acquired cultures of intolerance, xenophobia, and closed-mindedness that retarded their development. According to Landes, starting in the 15th century or even earlier, Catholic countries of southern Europe and Latin America, egged on by the Church, burned heretics, forbade learning and travel by their citizens, censored books, and restricted the inflow of new ideas. In part, the Catholic Church felt threatened by other religions emerging from the Protestant Reformation, and in part it wanted to extend its influence. The consequences of such intolerance were both the enormous increase in the power of church and state as they dedicated substantial resources to keeping out new ideas, and the inability of Catholic countries to learn from others. Landes believes that this intolerance was responsible for the decline of Spain, Portugal, and Italy, for poverty of Latin America, and for many other ills. Similarly, the decline of Muslim countries after the 13th century (that followed the golden age of openness and prosperity) is also explained by the newly found but long-lasting intolerance as a means of political and religious control.

Many cultural explanations of institutions and policies have a political element to them, as Landes's emphasis on the use of intolerance for political ends makes clear. Thus the Spanish Inquisition might have been the supreme example of Catholic intolerance that Landes takes it to be. But it was, in the first place, a political attempt by Ferdinand and Isabella to wrest control over religion from Rome by organizing religious life around the courts of Inquisition paid for by the Crown (Kamen, 1997). Similarly, the Church throughout the Catholic world has fought the State to tax and regulate the citizenry (Barraclough, 1972; Putnam, 1993; Finer, 1997; Mack Smith, 1997). It ultimately lost, but not before making a significant imprint on the governments of these 
countries. ${ }^{5}$ Interestingly, as Huntington (1991) explains, the Catholic Church in the 1960s switched from being a powerful force against liberalism (and therefore a source of poor culture, according to Landes) to a powerful force toward democratization, presumably again for the political reason of trying to maintain membership. Perhaps in part as a consequence, most of the countries that have democratized in the last 30 years, including Portugal, Spain, Poland, Hungary, Philippines, Nicaragua, Argentina, Brazil, and Mexico, have been Catholic. Finally, one could argue that Tokugawa Japan-perhaps the most intolerant and xenophobic polity of them all-changed its policies in the Meiji Restoration because the cultural beliefs of the officials have become more "Western" (Beasley, 1972). But there is an obvious political explanation: the political interests of the Tokugawa shoguns, namely controlling internal threats, were very different from those of the Meiji reformers, namely addressing the external threat. In short, culture appears to be quite often shaped by politics.

\subsection{Developing Hypotheses}

Our goal is to look for exogenous variation in economic, political, and cultural circumstances across countries that may account for the variation in government performance. Finding such exogeneity is rather difficult. Economists looked at such variables as government consumption (Barro, 1991), democracy (Barro, 1996a), corruption (Mauro, 1995), and institutional quality (Knack and Keefer, 1995) as determinants of economic growth. More recently, Hall and Jones (1999) have examined institutional quality, size of government, openness to trade, and private ownership as determinants of productivity across countries and made the brave argument that productivity is unlikely itself to influence institutions. From our perspective, of course, the quality of government is endogenous; to understand what determines government performance, and to distinguish between theories, we need to look at the more fundamental, or at least historically predetermined, variables.

From this perspective, economic theories of institutions are the hardest to test. The thrust of these theories is that economic development itself creates a demand for good government, and hence the appropriate measure of demand is per capita income. Based on this logic, our test of economic theories is to consider per capita income as a potential determinant of government performance. But good institutions themselves improve economic conditions. For example, we would expect better protection of property, improved government efficiency, higher quality private goods, perhaps big but good government, and perhaps political freedoms to enhance per capita income. We therefore have a relatively weak test of economic theories and, in fact, the article focuses on other determinants of government performance.

We use two strategies to identify the relevance of political theories of institutions. The first measure of the State's predisposition to major redistribution

5. DeToqueville (1858) discusses the motivation of French revolutionaries by noting that "to overthrow the institutions of existing social order they must begin by destroying those of the Church, on which they were modeled and from which, indeed, they derived" (p. 151). 
is ethnic heterogeneity [see, e.g., Mauro (1995); Alesina, Baqir, and Easterly (1999); Easterly and Levine (1997)]. In ethnically heterogeneous societies, it has been common for the groups that come to power to fashion government policies that expropriate (or kill) the ethnic losers, restrict their freedom of opposition, and limit the production of public goods to prevent those outside the ruling group from also benefiting and getting stronger. Alesina, Baqir, and Easterly (1999) offer a theory in which disagreement over the nature of preferred public goods leads ethnically heterogeneous societies to demand fewer of those goods, but there are many other-much more hostile-mechanisms through which heterogeneity can undermine government performance. The political theories predict that, as ethnic heterogeneity increases, governments become more interventionist and less efficient, and the quality of public goods falls, as does the size of government and political freedom. ${ }^{6}$

Our second strategy for evaluating political theories is to consider each country's legal origin. We divide national commercial legal traditions into common law, French civil law, German civil law, Scandinavian law, and socialist law. These traditions were developed in England, France, Germany, Scandinavia, and the Soviet Union but then spread through the world through conquest, colonization, imitation, and voluntary adoption. The distinctions between the French, German, and Scandinavian families are relatively subtle (as we discuss below), but the distinctions between socialist, civil, and common law traditions are not.

To begin, socialist law is a clear manifestation of the State's intent to create institutions to maintain its power and extract resources, without much regard for protecting the economic interests or the liberties of the population. The goal of socialist law is to keep the Communist Party in power, not to protect property or freedom.

Civil law, particularly since the time of Codification in the 19th century, has also been largely an instrument of the State in expanding its power, though in a more constrained way than socialist law [see Elster, Offe, and Press (1997:39); Finer (1997:1564)]. It is not surprising that the principal legal codes of the world were introduced by the two greatest State builders of the 19th century: Napoleon and Bismarck. Civil law is largely legislature created and is focused on discovering a just solution to a dispute (often from the point of view of the State) rather than on following a just procedure that protects individuals against the State (David and Brierley, 1978:331). Amusingly, René David - whose book can be fairly seen as a treatise on the superiority of civil law over common law-is surprised at France's weakness in the area of public law that deals with restraints on public officials (David and Brierley, 1978:76). ${ }^{7}$ A civil legal tradition, then, can be taken as a proxy for an intent

6. One can alternatively argue that ethnic heterogeneity is related to ethnic hatred, which is cultural rather than political. Often, though not always, ethnic hatred seems to have political antecedents.

7. An illustration is worth quoting in full: "Thus a taxpayer, even in the absence of any textually established right or some error committed in his case, can bargain with the tax authorities or obtain 
to build institutions to further the power of the State, although not to the same extent as in the socialist tradition.

The English common law tradition is entirely different in that its development starting in the 17th century has been shaped by Parliament and the aristocracy at the expense of the Crown, and hence it has reflected to a much greater extent the intent to limit the power of the sovereign (David and Brierley, 1978:303; Finer, 1997:1347-1348). As a result of this influence, the judges who made common law "put their emphasis on the private rights of individuals and especially on their property rights" (Finer, 1997:1348). There is also more emphasis on restraining the government and on protecting the individual against the government. A common law tradition, then, can be taken as a proxy for the intent to limit rather than strengthen the State.

In our earlier work (La Porta et al., 1997a, 1998) we considered legal traditions in a narrower context of examining legal protection of investors and the effect of such protection on capital markets. Here we use legal traditions as cruder proxies for the political orientation of governments. Most clearly, we expect that countries with socialist laws have the most interventionist governments, next come countries with civil laws, and finally common law countries. We would predict the same ordering for political freedom. In other dimensions of the quality of government, however, the relationships might be more complicated.

We expect that government efficiency is the lowest in socialist law countries, in part because the extreme power of the State corrupts the bureaucracies. We also expect that government efficiency should be high in common law, Scandinavian, and German civil law countries, despite the interventionist stance of the law in the latter two groups, largely because these countries have managed to build professional rather than patrimonial bureaucracies based on the armies and professional civil servants rather than aristocrats and clerics (Ertman 1997; Finer 1997). We expect the French civil law countries to be intermediate in government efficiency because the bureaucracy was built to be powerful and largely unconstrained. Having made these conjectures, we note that our theoretical and historical priors in this dimension of government performance are relatively weak.

The predicted effects of the legal systems on public good provision and government spending are not entirely straightforward either. We expect socialist law countries, in part because of their commitment to equality and in part because of their militarism, to do well on education and infant mortality, though not necessarily on infrastructure. With respect to public good provision and the size of government, we have no strong priors: civil law countries may have a greater interest in state expansion but a lower ability to tax than the common law countries. A more interventionist state is not necessarily a larger one.

a release in view of his special circumstances. According to the French Ministere de l'economie et des finances, about 200,000 taxpayers each year obtain some reduction in or release from taxes upon an appeal to the bienveillance of the administration. Le Monde, August 9, 1968" (David and Brierley, 1978:77). 
One possible concern with using legal systems as independent variables is that they are, to some extent, endogenous-a symptom of the relative power of the State and its subjects rather than the cause. Thus common law acquired its rules because the Crown was weak in the first place, and not the other way around. But this concern, while legitimate, makes legal systems particularly appropriate independent variables for testing political theories of institutions. Suppose that legal systems, which were acquired centuries ago as part of the political process (both voluntarily and not), are found to influence government performance today. This would mean that the historically determined political allocation of power, as reflected in the law, shapes government performance today, precisely as the political theory predicts. Despite their historical endogeneity, legal variables serve our empirical purpose extremely well.

Finally, we come to the cultural theories. Following Weber (1958), Putnam (1993), and Landes (1998), our proxy for the dimension of culture that influences government performance is religion-more precisely, the percentage of population in each country belonging to different religious affiliations. In an earlier article (La Porta et al., 1997b) we provided some evidence that countries whose populations belong primarily to what we called "hierarchical religions"-Catholicism, Islam, and Greek Orthodox-exhibit inferior government performance to that of largely Protestant countries. In this article we separate out the three most widespread religions-Muslim, Catholic, and Protestant—from all others. ${ }^{8}$ We also focus on Muslim and Catholic religions because Landes (1998) singles them out as particularly detrimental to development.

To begin, we note that cultural theories typically do not focus on government. Weber (1958) is interested in entrepreneurship, Putnam (1993) focuses on public good provision, and Landes (1998) is concerned with the flow of people, goods, and ideas between countries. Nonetheless, we try to develop some hypotheses for the effects of religion on governments.

It is probably fair to say that both Muslim and Catholic countries would be viewed by the adherents of cultural theories as being more interventionistin part because the doctrines of these religions are more interventionist (they like to tell people what to do) than Protestantism, and in part because these religions grew to support State power. Cultural theories would probably also predict that governments in predominantly Catholic and Muslim countries are less efficient partly as a consequence of excessive power, and partly because bureaucracies in these countries, particularly the Catholic ones, have developed from religious ranks (clerk comes from cleric), and hence were not as dependent on the sovereign. Cultural theories would definitely predict inferior provision of public goods in Muslim and Catholic countries, although Putnam's story here is a bit political: religion competes with, and undermines, the State in the provision

8. We do not focus on the Orthodox religion here because it is not as widespread as the other three and because many people in (at least formerly) Orthodox, but later on socialist, countries report to be nonreligious. 
of public goods. ${ }^{9}$ We would not even conjecture what these theories predict for government consumption. Finally, these theories, particularly Landes (1998), would surely predict that Muslim and Catholic countries have fewer civil rights: the State-supported intolerance in these countries requires a curtailment of freedom to be carried out. (Remember, however, the switch by the Catholic Church after Vatican II in the 1960s.)

\section{Data}

Our analysis is based on a dataset of measures of government performance and their potential determinants in (up to) 152 countries. Since we are combining a large number of datasets, we have different numbers of observations for different variables, with some regressions covering as few as 47 countries. The data typically also come from different years, although most of the data are from the 1990s. The definitions and sources for all the variables used in this article are summarized in Table 1; Appendices A and B present summary statistics and the data on the independent variables.

To gain robustness, we try to use as our measures of government performance both objective and survey measures from different data sources. This is particularly important for subjective assessments of government performance, since within the same survey responses to different questions may simply reflect some general underlying sentiment toward a country. When different surveys use different respondents, this risk is reduced.

We measure government intervention by an index of property rights protection, an index of the quality of business regulation, and the top marginal tax rate. We measure government efficiency by survey scores on corruption, bureaucratic delays, and tax compliance. We also include in this category a measure of relative wages of government officials to see if higher wages are associated with more efficient government. We measure the output of public goods by infant mortality, school attainment, illiteracy, and an index of infrastructure quality. (With illiteracy and infant mortality, we depart from the convention that higher values of the measure refer to better performance.) We measure the size of the public sector by government transfers and subsidies, government consumption, an index of the size of the state enterprise sector (higher value means smaller), and a measure of the relative size of public sector employment. Finally, we use indices of democracy and of political rights in our democracy category.

Table 2 presents the correlations between the dependent variables, which reveal a number of fascinating patterns. The correlations between measures of government performance within the same category are generally high. In the intervention category, there is a positive correlation between property rights protection and the business regulation index, but the top tax rate is not significantly related to these two measures of government intervention. This result

9. Another version of the cultural story is that religions that require their followers to read the sacred texts (such as Protestantism) encourage literacy, whereas religions that rely on the auditory absorption of information (such as Catholicism) discourage literacy. 
Table 1. Description of the Variables

\begin{tabular}{|c|c|c|}
\hline Variable Name & Description and Source & $\begin{array}{r}\text { Number of } \\
\text { Observations }\end{array}$ \\
\hline \multicolumn{3}{|c|}{ Interference with the private sector: } \\
\hline $\begin{array}{l}\text { Property } \\
\text { rights } \\
\text { index }\end{array}$ & $\begin{array}{l}\text { A rating of property rights in each country } \\
\text { (on a scale from } 1 \text { to 5). The more protection } \\
\text { private property receives, the higher the score. } \\
\text { The score is based, broadly, on the degree of legal } \\
\text { protection of private property, the extent to which } \\
\text { the government protects and enforces laws that } \\
\text { protect private property, the probability that } \\
\text { the government will expropriate private property, } \\
\text { and the country's legal protection to private } \\
\text { property. Source: Holmes, Johnson, and } \\
\text { Kirkpatrick, } 1997 \text {. }\end{array}$ & 149 \\
\hline $\begin{array}{l}\text { Business } \\
\text { Regulation } \\
\text { index }\end{array}$ & $\begin{array}{l}\text { A rating of regulation policies related to } \\
\text { opening a business and keeping open a } \\
\text { business (on a scale from } 1 \text { to } 5 \text { ). Higher } \\
\text { score means that regulations are straight-forward } \\
\text { and applied uniformly to all businesses and that } \\
\text { regulations are less of a burden to business. Source: } \\
\text { Holmes, Johnson, and Kirkpatrick, } 1997 \text {. }\end{array}$ & 149 \\
\hline Top tax rate & $\begin{array}{l}\text { Top marginal tax rate for each country } \\
\text { in 1994. Source: Gwartney, Lawson, and } \\
\text { Block, } 1996 .\end{array}$ & 82 \\
\hline \multicolumn{3}{|l|}{ Efficiency: } \\
\hline Corruption & $\begin{array}{l}\text { Corruption in government index. Low } \\
\text { ratings indicate "high government officials } \\
\text { are likely to demand special payments" and } \\
\text { "illegal payments are generally expected thought } \\
\text { lower levels of government" in the form of } \\
\text { "bribes connected with import and export } \\
\text { licenses, exchange controls, tax assessment, } \\
\text { policy protection, or loans." Scale from } 0 \\
\text { to 10. Average of the months of April and } \\
\text { October in the monthly index between } 1982 \\
\text { and 1995. Source: Political Risk } \\
\text { Services, various years. }\end{array}$ & 126 \\
\hline $\begin{array}{l}\text { Bureaucratic } \\
\text { delays }\end{array}$ & $\begin{array}{l}\text { An indicator of bureaucratic delays } \\
\text { (red tape). Low ratings indicate lower } \\
\text { levels of red tape in the bureaucracy of the } \\
\text { country. Scale from } 0 \text { to } 10 \text {. The index is } \\
\text { published three times per year. The data is } \\
\text { the average of the years between } 1972 \text { and } \\
\text { 1995. Source: Business Environmental Risk } \\
\text { Intelligence's (BERI) Operation Risk Index. }\end{array}$ & 60 \\
\hline Tax compliance & $\begin{array}{l}\text { Assessment of the level of tax } \\
\text { compliance. Scale from } 0 \text { to 6, where higher } \\
\text { scores indicate higher compliance. Data is } \\
\text { for 1995. Source: World Economic Forum, } 1996 .\end{array}$ & 49 \\
\hline
\end{tabular}


Table 1. Continued

\begin{tabular}{|c|c|c|}
\hline $\begin{array}{l}\text { Avg. government } \\
\text { wages/GDP per } \\
\text { capita }\end{array}$ & $\begin{array}{l}\text { The ratio of average wages of } \\
\text { central government to per capita } \\
\text { GDP in each country. Certain non-wage } \\
\text { benefits are not included in the estimate of } \\
\text { the average central government wage. Source: } \\
\text { Schiavo-Campo, de Tommaso and Mukherjee, } 1997 .\end{array}$ & 63 \\
\hline \multicolumn{3}{|c|}{ Output of public goods: } \\
\hline $\begin{array}{l}\text { Log of infant } \\
\text { mortality }\end{array}$ & $\begin{array}{l}\text { Logarithm of the number of } \\
\text { deaths of infants under one year } \\
\text { of age per one thousand live births for } \\
\text { the years 1970-1995. Source: World } \\
\text { Bank, World Development Indicators } \\
1997 \text { (WDI). }\end{array}$ & 196 \\
\hline $\begin{array}{l}\text { Log of school } \\
\text { attainment }\end{array}$ & $\begin{array}{l}\text { Log of schooling taken over } \\
\text { five year periods (1960-65, } \\
1970-75 \text {, and 1980-85). Each value is } \\
\text { obtained as the logarithm of }(1+\text { average } \\
\text { years of school attainment during the } \\
\text { respective period). Source: Barro } \\
\text { and Lee, } 1994 \text {. }\end{array}$ & 106 \\
\hline Illiteracy rate & $\begin{array}{l}\text { Average of adult illiteracy } \\
\text { rate for the years } 1990-1995 \text {. Adult } \\
\text { illiteracy rate is the proportion of adults } \\
\text { aged } 15 \text { and above who cannot, with } \\
\text { understanding, read and write a short, } \\
\text { simple statement on their everyday life. } \\
\text { 1990-1995. Scale } 0 \text { to 100. Source: WDI. }\end{array}$ & 128 \\
\hline $\begin{array}{l}\text { Infrastructure } \\
\text { quality }\end{array}$ & $\begin{array}{l}\text { Assessment of the "facilities } \\
\text { for and ease of communication between } \\
\text { headquarters and the operation, and within the } \\
\text { country," as well as the quality of the } \\
\text { transportation. Average data for the years } \\
1972 \text { to } 1995 \text {. Scale from } 0 \text { to } 10 \text { with higher } \\
\text { scores for superior quality. Source: } \\
\text { BERI's Operation Risk Index. }\end{array}$ & 60 \\
\hline \multicolumn{3}{|c|}{ Size of public sector: } \\
\hline $\begin{array}{l}\text { Transfers and } \\
\text { subsidies/GDP }\end{array}$ & $\begin{array}{l}\text { Total government transfers and } \\
\text { subsidies as a percentage of GDP } \\
\text { (scale from } 0 \text { to 100). Average for the } \\
\text { years 1975-1995. Source: Gwartney, } \\
\text { Lawson, and Block, } 1996 \text { (with data } \\
\text { from the World Bank and International } \\
\text { Monetary Fund). }\end{array}$ & 90 \\
\hline
\end{tabular}


Table 1. Continued

\begin{tabular}{ll}
\hline Government & Government consumption expenditures \\
consumption/ & as a percentage of GDP (scale from \\
GDP & o to 100). Average for the years 1975-1995. \\
& Government consumption expenditures "include \\
& all spending on goods and services purchased \\
& by the government-things like national \\
& defense, road maintenance, wages and salaries, \\
& office space, and government-owned vehicles. \\
& Since it is obtained from the national \\
& income accounts, it includes all levels \\
& of government spending. It does not include \\
& direct transfers and subsidies, since these \\
& do not enter into the national income accounts." \\
& Source: Gwartney, Lawson, and Block, 1996 \\
& (with data from the World Bank and International \\
& Monetary Fund). \\
& Index of State-Owned Enterprises
\end{tabular}

economy as a share of the economy (scale from

0 to 10). Higher scores include countries with

less government-owned enterprises which are estimated to produce less of the country's output.

As the estimated size and breadth of the SOE sector increases, countries are assigned lower ratings. Average of the score for the years 1975-1995.

Source: Gwartney, Lawson, and

Block, 1996

Public sector Average of the ratio of public sector employment

in general government to total population

population

for the years 1976-1996. General government employment includes employment in "all government department offices, organizations and other bodies which are agencies or instruments of the central or local authorities whether accounted for or financed in, ordinary or extraordinary budgets or extra-budgetary funds. They are not solely engaged in administration but also in defense and public order, in the promotion of economic growth and in the provision of education, health and cultural and social services." Source: Schiavo-Campo, de Tommaso, and Mukherjee, 1997.

Political freedom:

Democracy index Average of democracy score for the period

1970-1994. Scale from 0 to 10, with lower values

indicating a less democratic environment. Source: Jaggers and Gurr, 1996.

Political rights Index of political rights. Higher ratings elections; (2) those elected rule; (3) there are competitive parties or other competitive political groupings; (4) the opposition has an important role and power; and (5) the entities have self-determination or an extremely high degree of autonomy." Source: Freedom House, 1996. 
238 The Journal of Law, Economics, \& Organization, V15 N1

Table 1. Continued




gets back to the earlier point: high taxes are not necessarily a sign of an inferior government.

In the government efficiency category, less corrupt countries also have fewer bureaucratic delays and higher tax compliance. Tax compliance and the score on bureaucratic delays are also positively correlated. These correlations support the view that corruption is another side of bureaucratic discretion, since delays create the opportunities to take bribes. Finally, corruption is negatively correlated with the relative wages of government officials. Contrary to the view that higher pay for bureaucrats is a remedy for corruption, the raw correlation suggests just the opposite. It is likely instead that in countries where bureaucrats have much power, they collect both higher wages and significant bribes. Consistent with this view as well, countries where the government is more efficient (including less corrupt) are on average also less interventionist.

The measures of public good output are highly correlated with each other. Low infant mortality, significant school attainment, low illiteracy, and highquality infrastructure typically come together. Countries with good public goods are also the ones with efficient government, low (!) relative government wages, and less intervention (except for the high top tax rate).

With the exception of the SOE index, the various measures of the size of government are strongly correlated with each other. Countries with more government consumption, transfers, and labor are less corrupt; they have fewer bureaucratic delays and better provision of public goods, but also higher tax rates. Figures 1 and 2 present the scatter plots of the corruption index and infant mortality, respectively, against government transfers and subsidies as a share of GDP. The scatter plots, and the correlations more generally, show clearly that bigger governments, while taxing more, look better on just about every measure of performance. This result, that the larger governments tend to be the higher quality ones, is one of our key findings. It does not imply, of course, that it is often desirable to expand a government of a given quality. ${ }^{10}$

The measures of democracy and political rights are highly correlated with each other. Freer governments are larger, more efficient, intervene less, and provide better public goods.

The correlations between the independent variables are presented in Table 3, and they too deliver interesting findings. We have three broad factors that may be related to government performance: ethnolinguistic fractionalization [measured, following Easterly and Levine (1997), as the average of several measures of ethnic diversity], the origin of commercial laws, and the religious composition of the population (the percentage of the population in the three most widespread religions). We also include latitude and (the log of) per capita income as control variables. We discussed per capita income already. We include (the scaled absolute value of) latitude because temperate zones have more productive agriculture and healthier climates, which has enabled them

10. Lindbeck (1997), for example, suggests that even a reasonably efficient government, such as that of postwar Sweden, can become too imposing to sustain economic growth. 
Table 2. Correlations of Dependent Variables

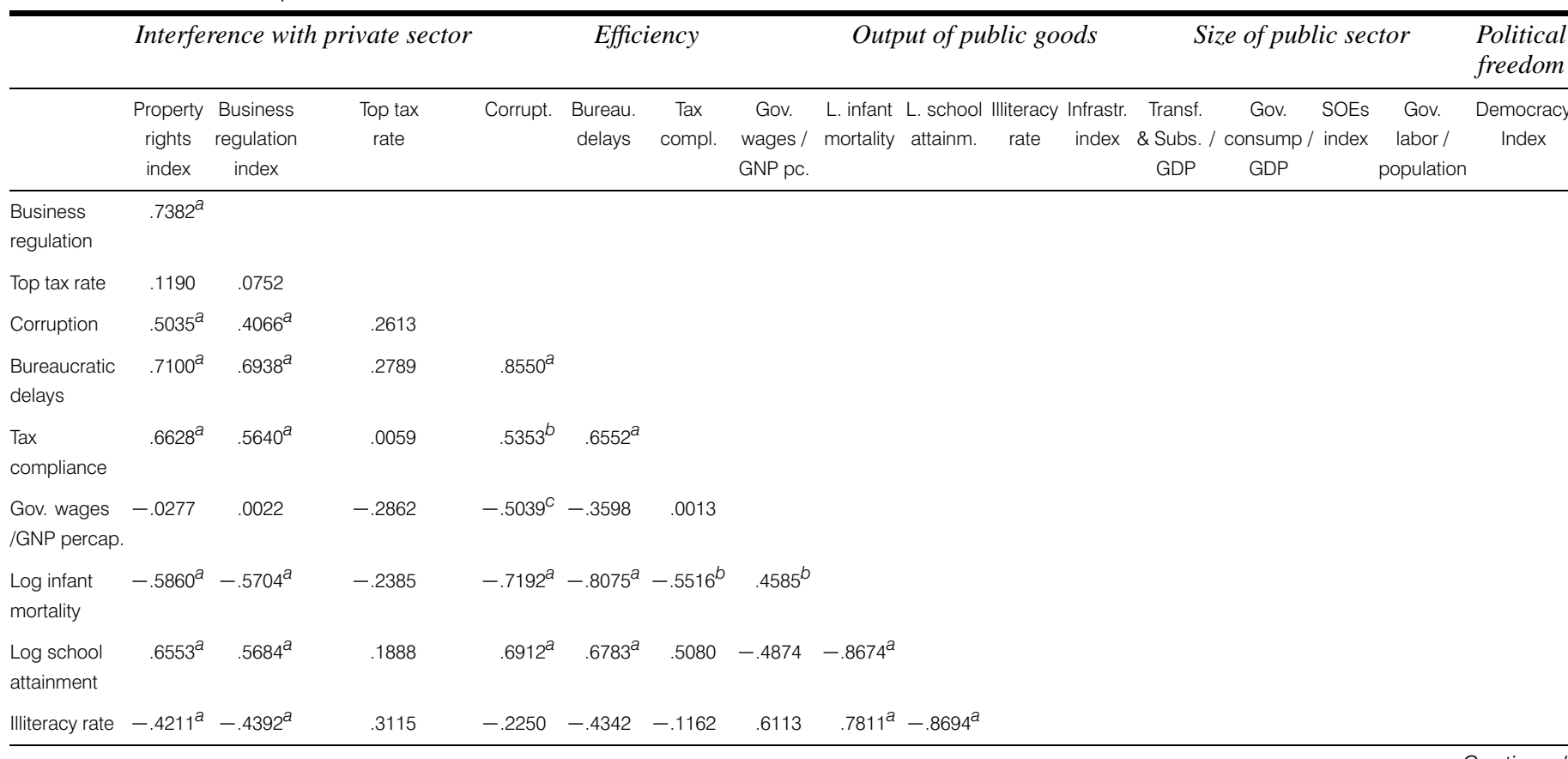


Table 2. Continued

\begin{tabular}{|c|c|c|c|c|c|c|c|c|c|c|c|c|c|c|c|c|}
\hline & \multicolumn{4}{|c|}{ Interference with private sector } & \multicolumn{3}{|c|}{ Efficiency } & \multicolumn{4}{|c|}{ Output of public goods } & \multicolumn{4}{|c|}{ Size of public sector } & \multirow{2}{*}{$\begin{array}{c}\begin{array}{c}\text { Political } \\
\text { freedom }\end{array} \\
\begin{array}{c}\text { Democracy } \\
\text { Index }\end{array}\end{array}$} \\
\hline & $\begin{array}{l}\text { Property } \\
\text { rights } \\
\text { index }\end{array}$ & $\begin{array}{l}\text { Business } \\
\text { regulation } \\
\text { index }\end{array}$ & $\begin{array}{l}\text { Top tax } \\
\text { rate }\end{array}$ & Corrupt. & $\begin{array}{l}\text { Bureau. } \\
\text { delays }\end{array}$ & $\begin{array}{l}\text { Tax } \\
\text { compl. }\end{array}$ & $\begin{array}{l}\text { Gov. } \\
\text { wages / } \\
\text { GNP pc. }\end{array}$ & $\begin{array}{l}\text { L. infant } \\
\text { mortality }\end{array}$ & $\begin{array}{l}\text { L. school } \\
\text { attainm. }\end{array}$ & $\begin{array}{l}\text { Illiteracy } \\
\text { rate }\end{array}$ & $\begin{array}{l}\text { Infrastr. } \\
\text { index }\end{array}$ & $\begin{array}{l}\text { Transf. } \\
\text { \& Subs. / } \\
\text { GDP }\end{array}$ & $\begin{array}{l}\text { Gov. } \\
\text { consump / } \\
\text { GDP }\end{array}$ & $\begin{array}{l}\text { SOEs } \\
\text { index }\end{array}$ & $\begin{array}{c}\text { Gov. } \\
\text { labor / } \\
\text { population }\end{array}$ & \\
\hline $\begin{array}{l}\text { Infrastructure } \\
\text { index }\end{array}$ & $.7410^{a}$ & $.6836^{a}$ & .4035 & $.8142^{a}$ & $.9298^{a}$ & $.6229^{a}$ & -.3429 & $-.7907^{a}$ & $.6793^{a}$ & -.3759 & & & & & & \\
\hline $\begin{array}{l}\text { G. consumpt. } \\
\text { /GDP }\end{array}$ & .1788 & .1884 & .3324 & $.4604^{a}$ & .4662 & .2402 & -.1852 & -.3300 & .2734 & .0012 & $.4686^{\mathrm{C}}$ & $.4005^{b}$ & & & & \\
\hline SOEs index & .2431 & .2950 & -.1683 & .1550 & $.5379^{a}$ & $.6008^{a}$ & .1657 & -.1794 & .1446 & -.1705 & $.4735^{\mathrm{C}}$ & -.2976 & -.1434 & & & \\
\hline $\begin{array}{l}\text { Gov. labor/ } \\
\text { population }\end{array}$ & $.3811^{b}$ & .3157 & .2692 & $.6077^{a}$ & .4703 & .3047 & -.4202 & $.7064^{a}$ & $.6833^{a}$ & $-.5207^{a}$ & $.4969^{b}$ & $.7222^{a}$ & $.5235^{a}$ & .0362 & & \\
\hline
\end{tabular}

${ }^{a}$ Significant at $1 \%$ level.

.

${ }^{c}$ Significant at 10\% leve. 
242 The Journal of Law, Economics, \& Organization, V15 N1

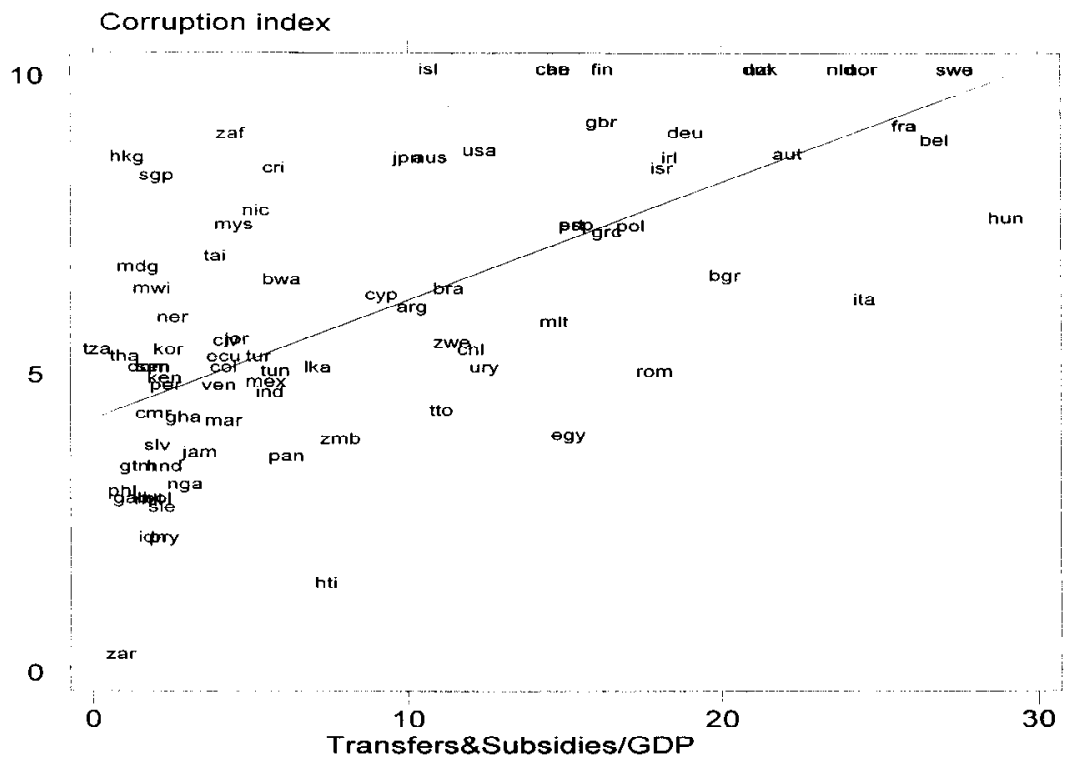

Figure 1. The size of government and corruption.

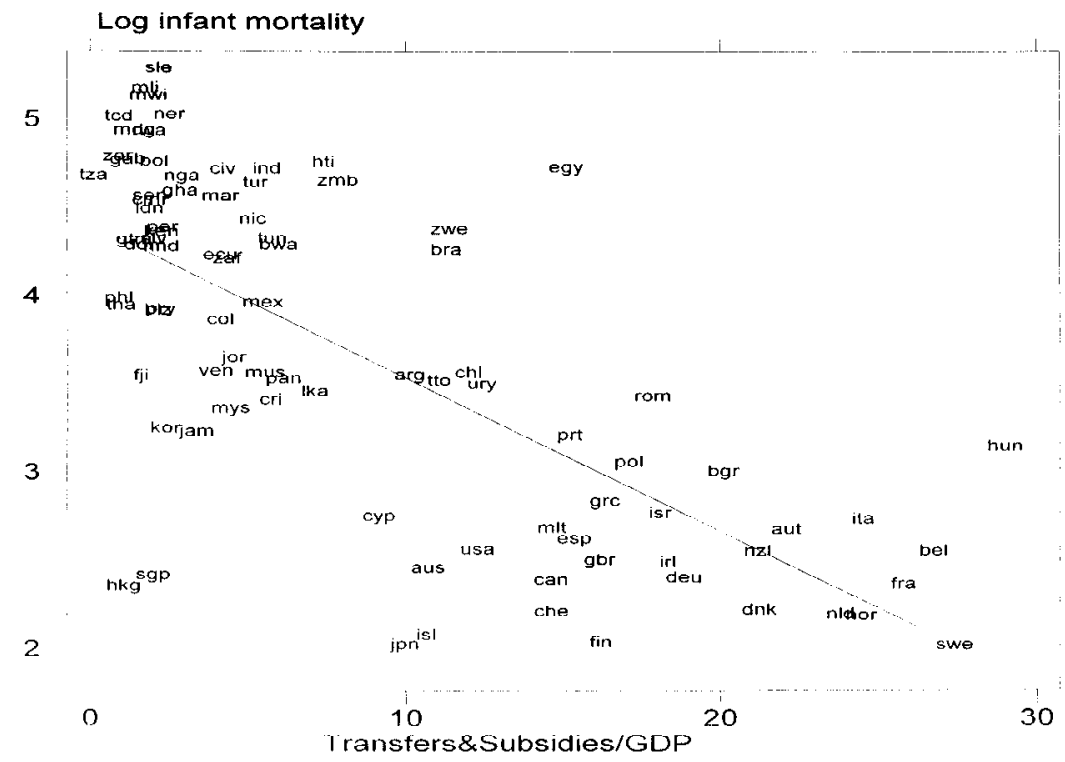

Figure 2. The size of government and infant mortality. 
The Quality of Government $\mathbf{2 4 3}$

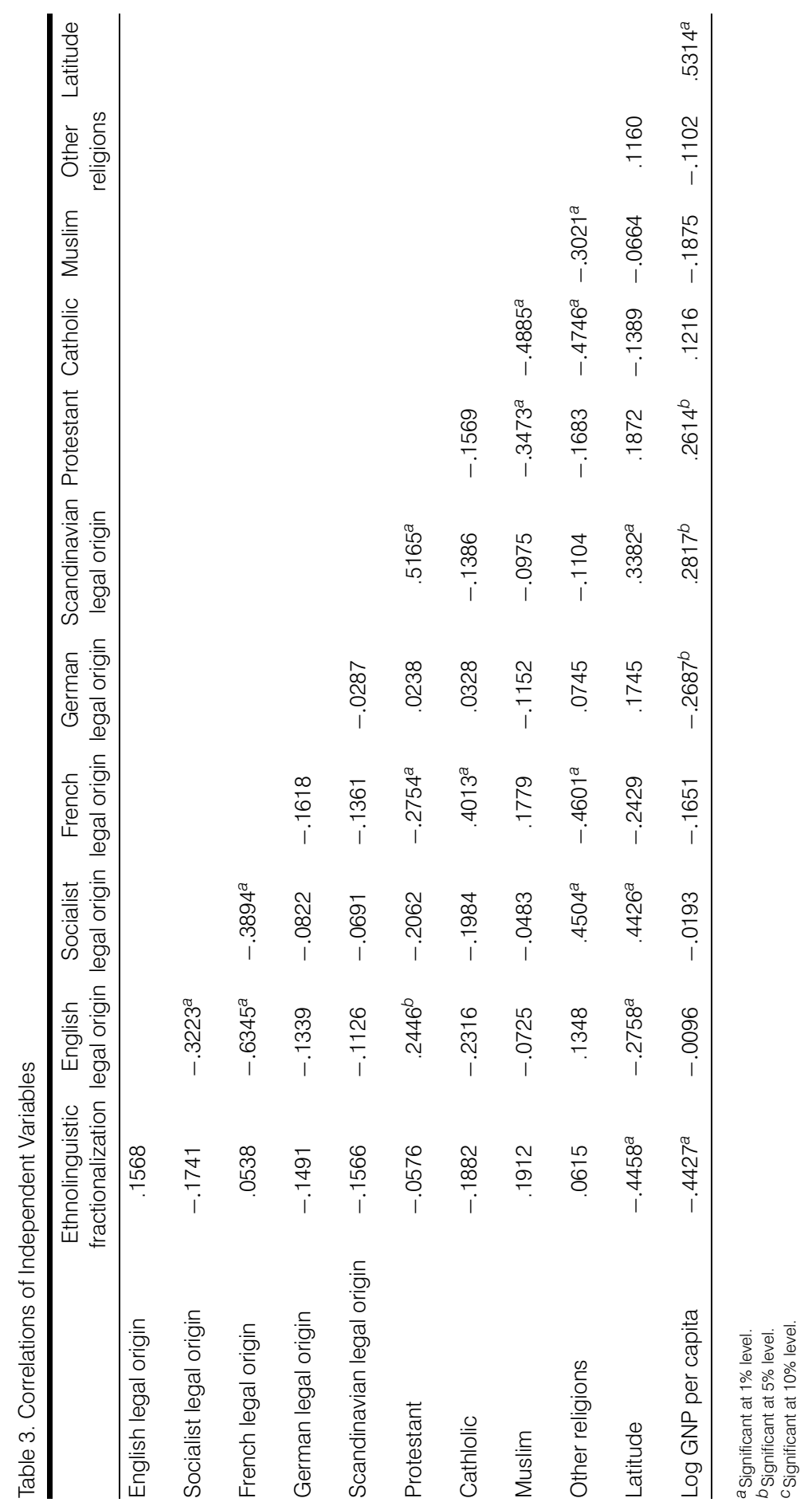


to develop their economies and possibly their institutions as well (Landes, 1998).

Ethnolinguistic fractionalization (EF) is unrelated to any of our religious or legal origin variables, but is significantly negatively correlated with latitude and per capita income. It is noteworthy that EF captures a different aspect of society than religion and law.

The correlations between the legal and religious variables are predictable, but important. First, there are significant negative correlations between the percentages of Protestants and Muslims, Catholics and Muslims, Catholics and other religions, and Muslims and other religions across countries. Second, Catholic countries typically have French legal origin; Protestant countries typically have an English or Scandinavian legal origin, and are less likely to have French legal origin; other religions are more likely to have a socialist legal origin, presumably because of the significant presence of Orthodox religions in socialist countries. Third, Scandinavian and German legal origin countries, as well as Protestant countries, are richer. Fourth, ethnolinguistically fractionalized and common law countries tend to be closer to the equator, whereas socialist and Scandinavian legal origin countries tend to be further away from it. Of course, Scandinavia and Germany have not had many colonies, and hence their legal traditions are restricted to wealthy European and East Asian countries.

\section{Regression Results}

In this section we present regressions of determinants of government performance. We present each regression both with and without the logarithm of per capita income and latitude controls. ${ }^{11}$ The argument for including per capita income (or for that matter, latitude) is that, on the economic theory of institutions, development improves government performance. ${ }^{12}$ On the other hand, good policies themselves enhance per capita income, and so a regression with truly exogenous independent variables should not include income. Including income in the regressions together with other determinants of performance would then spuriously reduce our estimates of the impact of these determinants on the quality of government. For example, if EF undermines government performance, and poor performance reduces per capita income, then including income in the regression of government performance on $\mathrm{EF}$ would reduce the estimated effect of the latter. We estimate the regressions both ways, and try to understand how the results depend on the specification.

We present the results in Tables 4-6. Since religious affiliations and legal

11. The logarithm of per capita income and latitude are strongly correlated with each other. We also ran the regressions including them one at a time. Each is nearly always significant when included alone. Countries that are further from the equator, or richer, have better government performance. We include them together because the correlation between them is not perfect.

12. Hall and Jones (1999) make the argument that per capita income (or productivity) should not have a direct effect on institutional quality, based on their impression that, in the United States, institutions were better in 1790 than in 1990. The economic theory of institutions, which Hall and Jones appear to endorse, argues that causation goes precisely in the opposite direction. 
origins are correlated with each other, and EF appears to be uncorrelated with either, we include legal origin and EF together as independent variables in Table 4 and religious affiliation and EF in Table 5. In Table 6 we include EF, legal origin, and religious affiliation.

Looking at Table 4 (or Table 5) we note that the logarithm of per capita income (and latitude) generally has a strong positive effect on government performance. Richer countries are less interventionist in that they protect property rights and regulate better, although they also have higher marginal tax rates. Richer countries also have more efficient governments, better provision of public goods, and-as Wagner law suggests-a larger public sector (except a smaller state enterprise sector).

The results on per capita income mean either that there is some merit to the economic theories of institutions, or that good governments promote development, or both. Consistent with the importance of the correlation between government performance and per capita income, the explanatory power of the regressions generally rises sharply when per capita income is included in the regressions. Having established the importance of this correlation, we can now turn to the central question: Do historical factors, as suggested by the political and cultural theories, help explain the variation in government performance across countries? As we show below, the answer is yes.

\subsection{Ethnolinguistic Fractionalization}

We discuss EF results based on Table 4, which only includes variables suggested by the political theories of institutions. The results on EF in Table 5 are similar. In the specifications excluding latitude and per capita income, EF has a very consistent adverse effect on government performance. Higher fractionalization is associated with more interventionism (worse property rights and regulation), lower government efficiency (more corruption, longer delays, lower tax compliance), inferior provision of public goods (higher infant mortality and illiteracy, lower school attainment and infrastructure quality), smaller government (transfers, consumption, and public employment), though more state enterprises, and finally less political freedom. The adverse effects of EF on government performance are broadly consistent with the argument that $\mathrm{EF}$ captures the predisposition of ethnic groups in power to redistribute.

The negative effect of EF on government performance generally becomes insignificant once we control for per capita income and latitude. (Recall that EF is itself negatively correlated with per capita income.) Controlling for how poor they are, ethnolinguistically fractionalized countries do not have especially bad governments. One exception to this finding is public good provision, which is inferior in divided countries even controlling for their poverty. Another exception is the prevalence of state ownership of firms, which is higher in divided countries even controlling for per capita income. The latter result is particularly noteworthy because state-owned enterprises are such an important mechanism of political redistribution. The effect of per capita income control may mean that $\mathrm{EF}$ adversely affects government performance, and bad performance in turn reduces per capita income, as the standard version of the political 


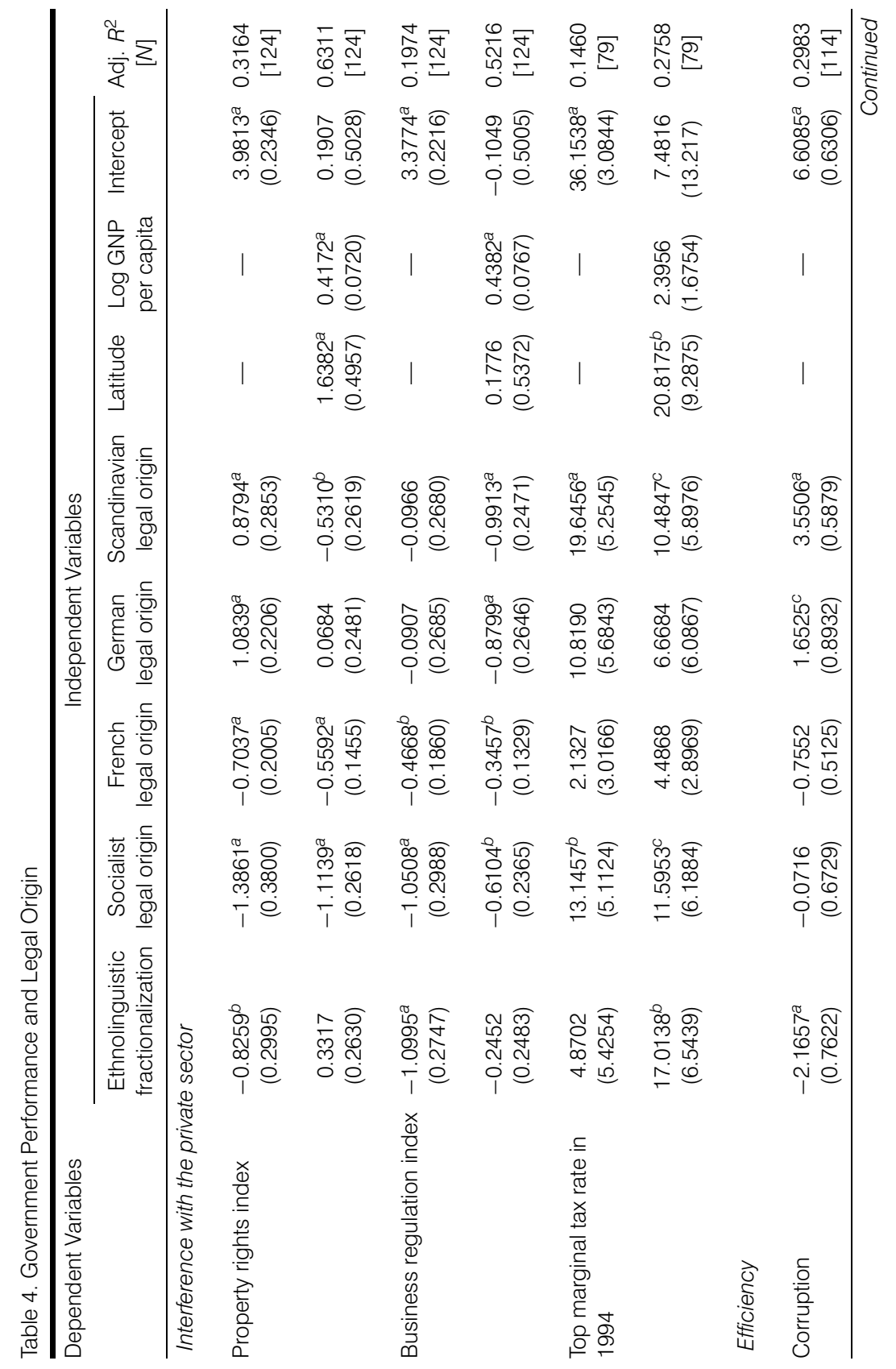




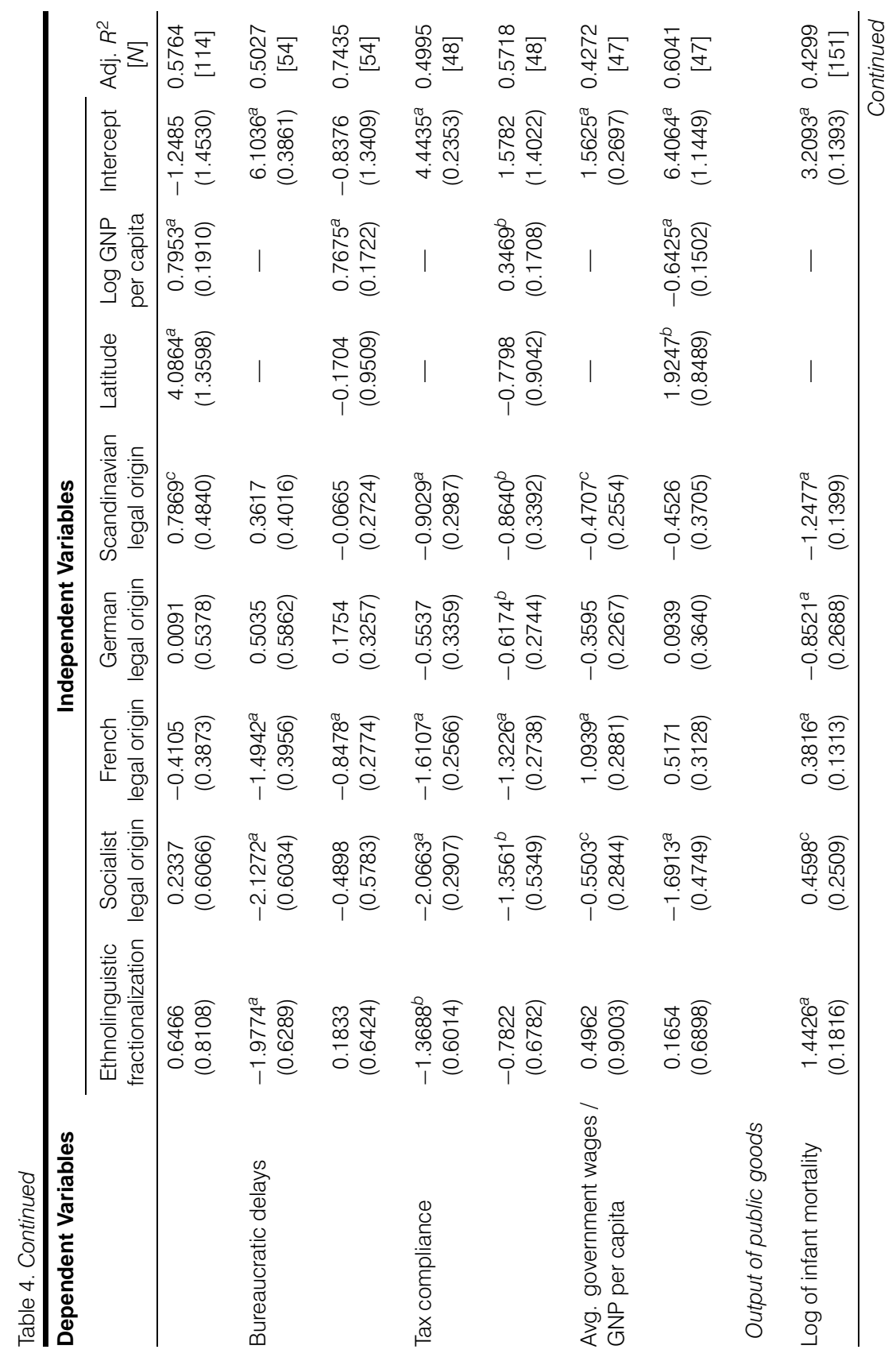




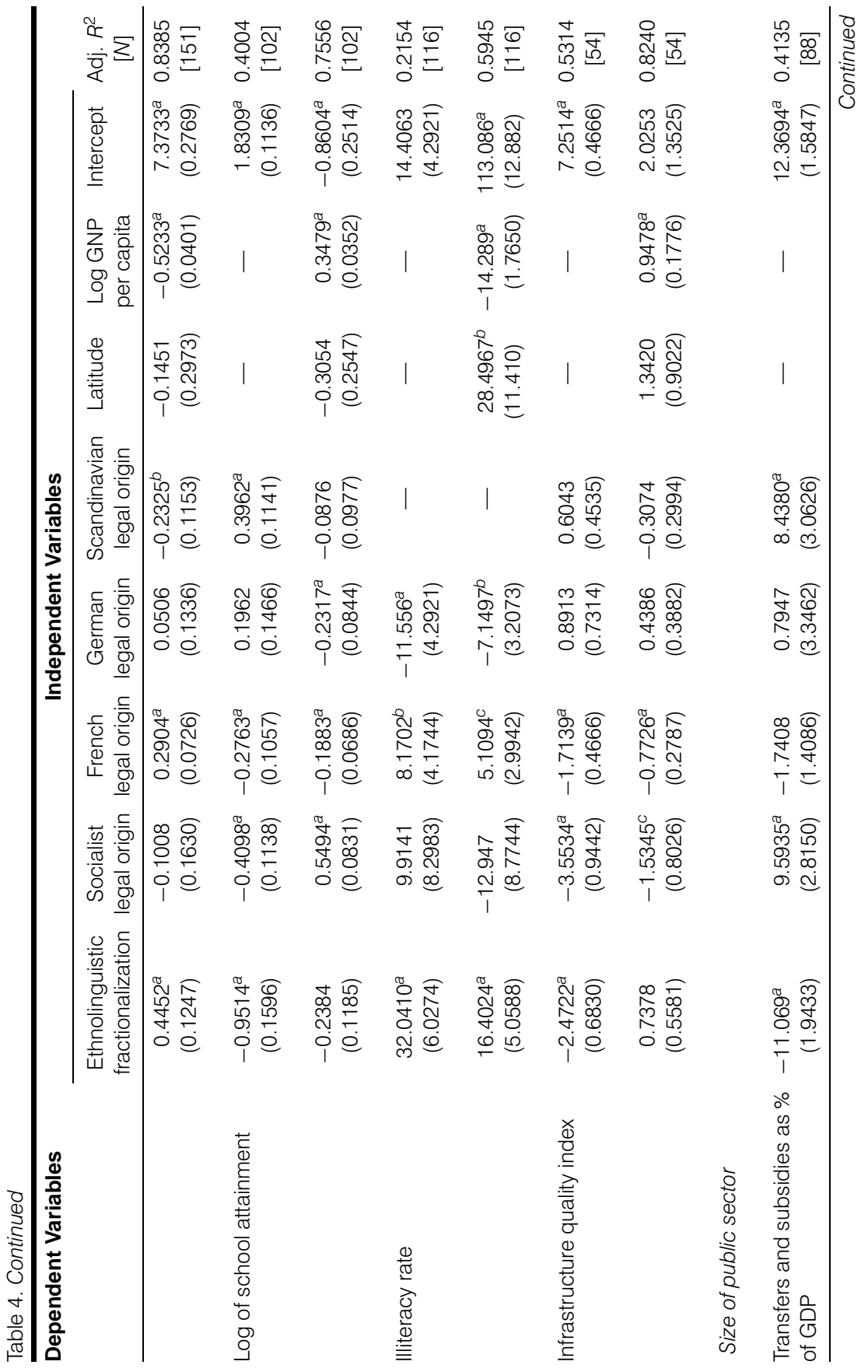




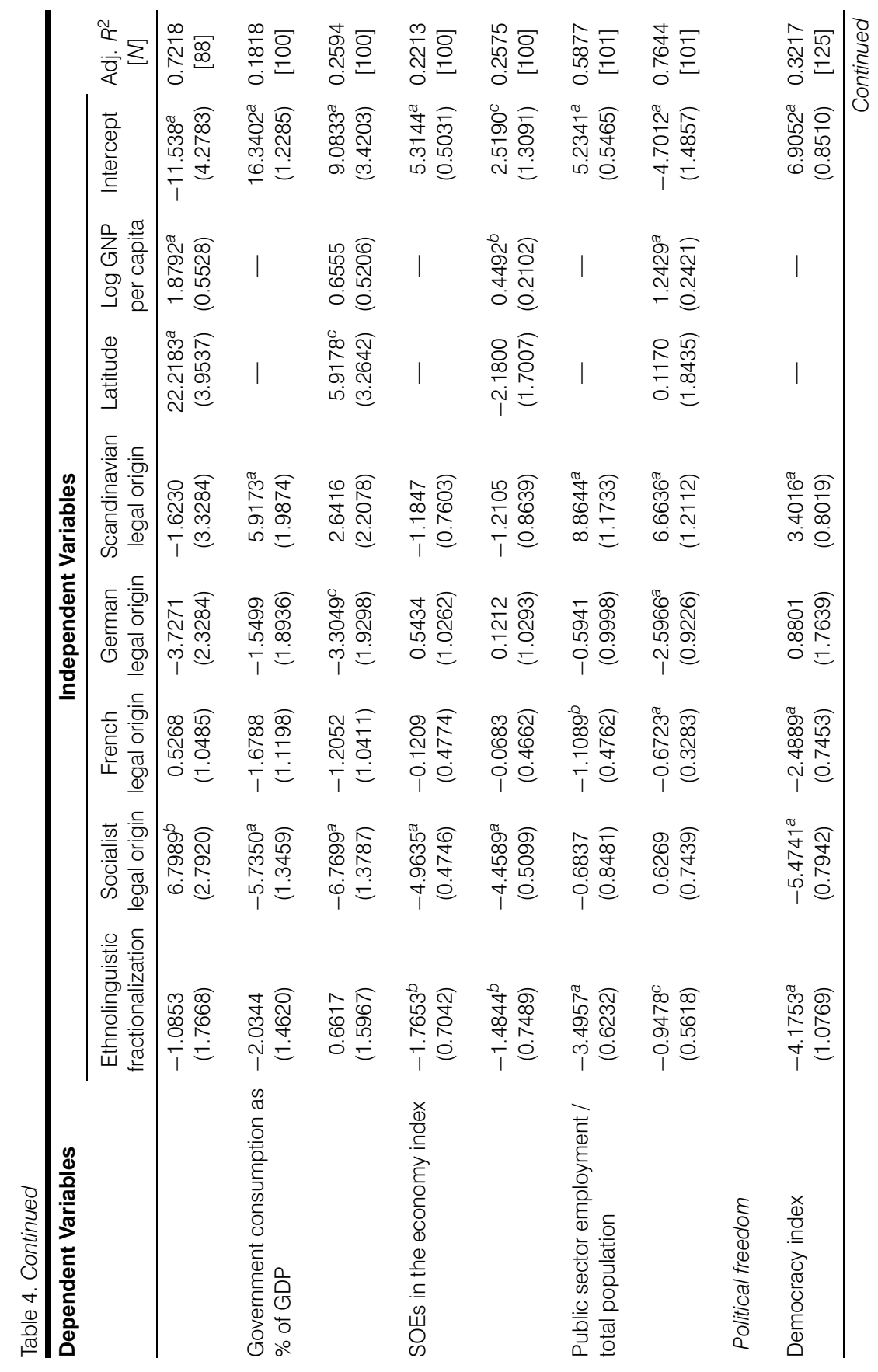




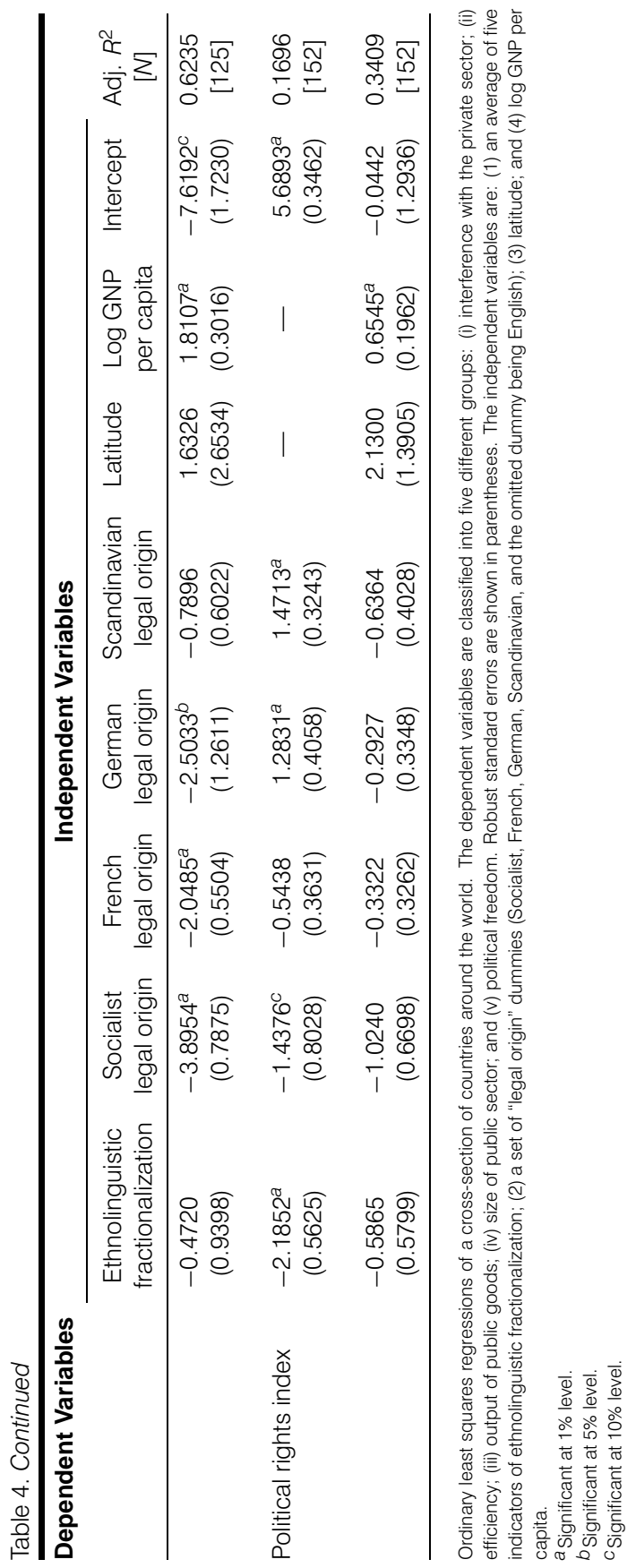




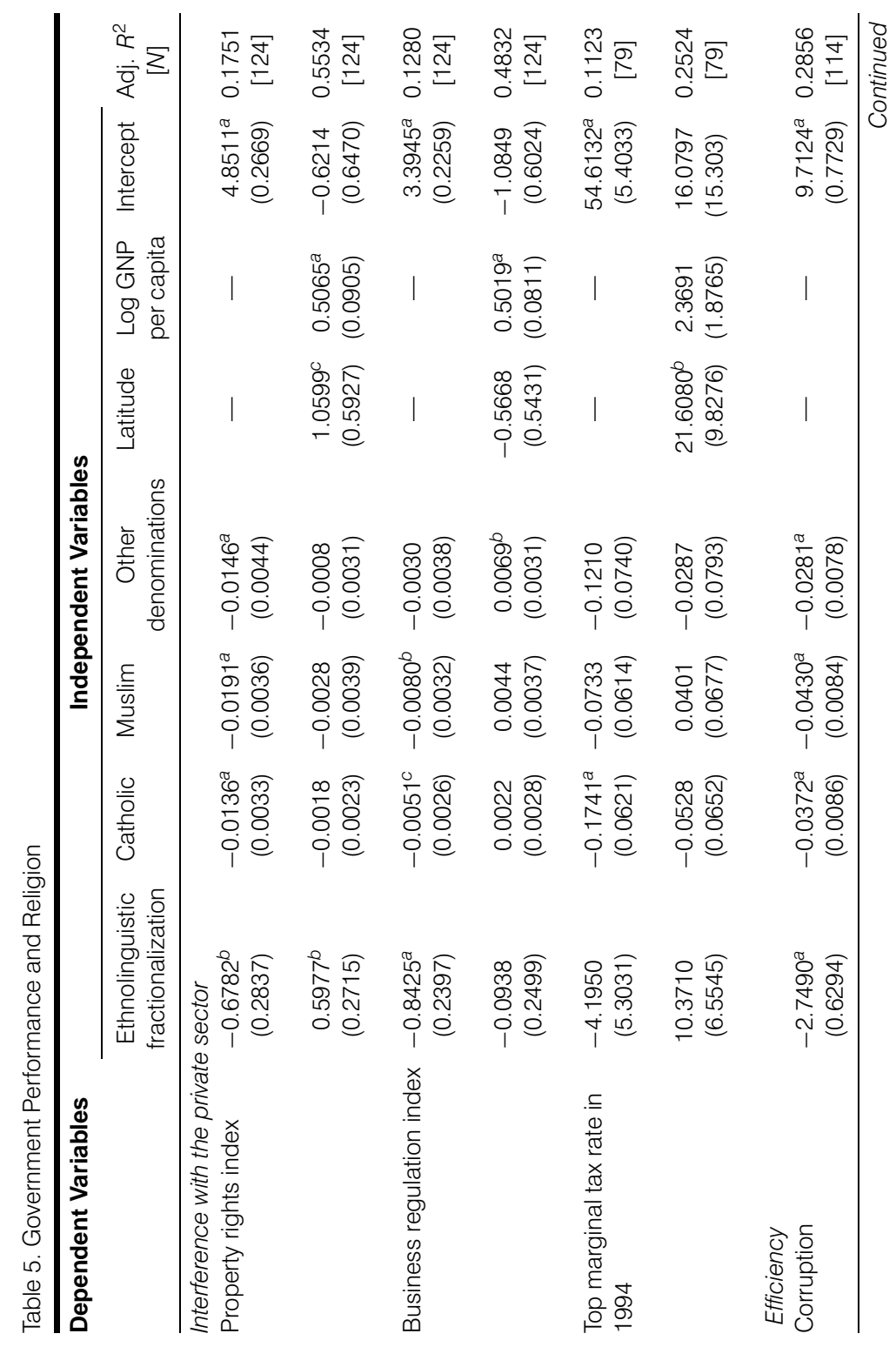




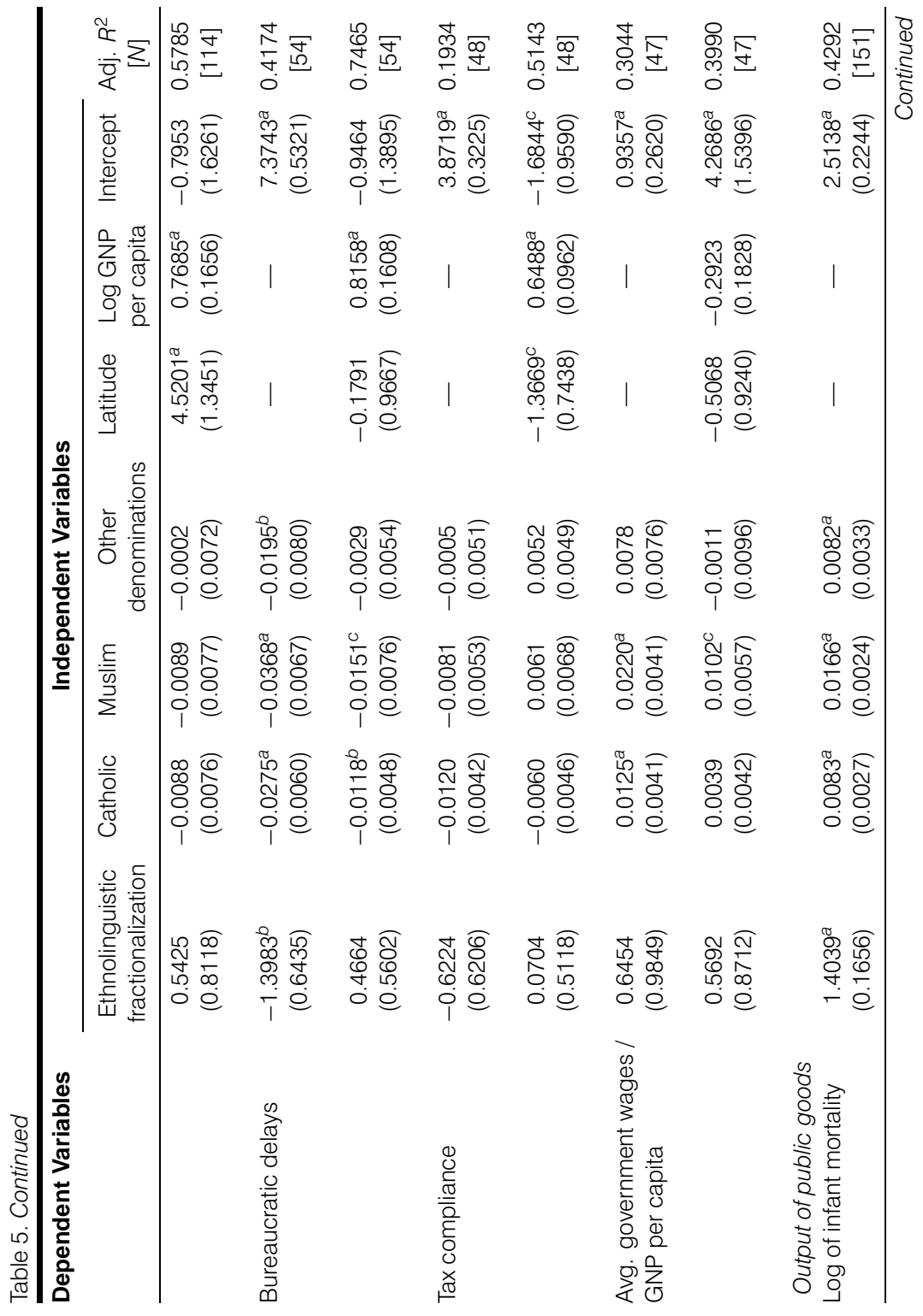




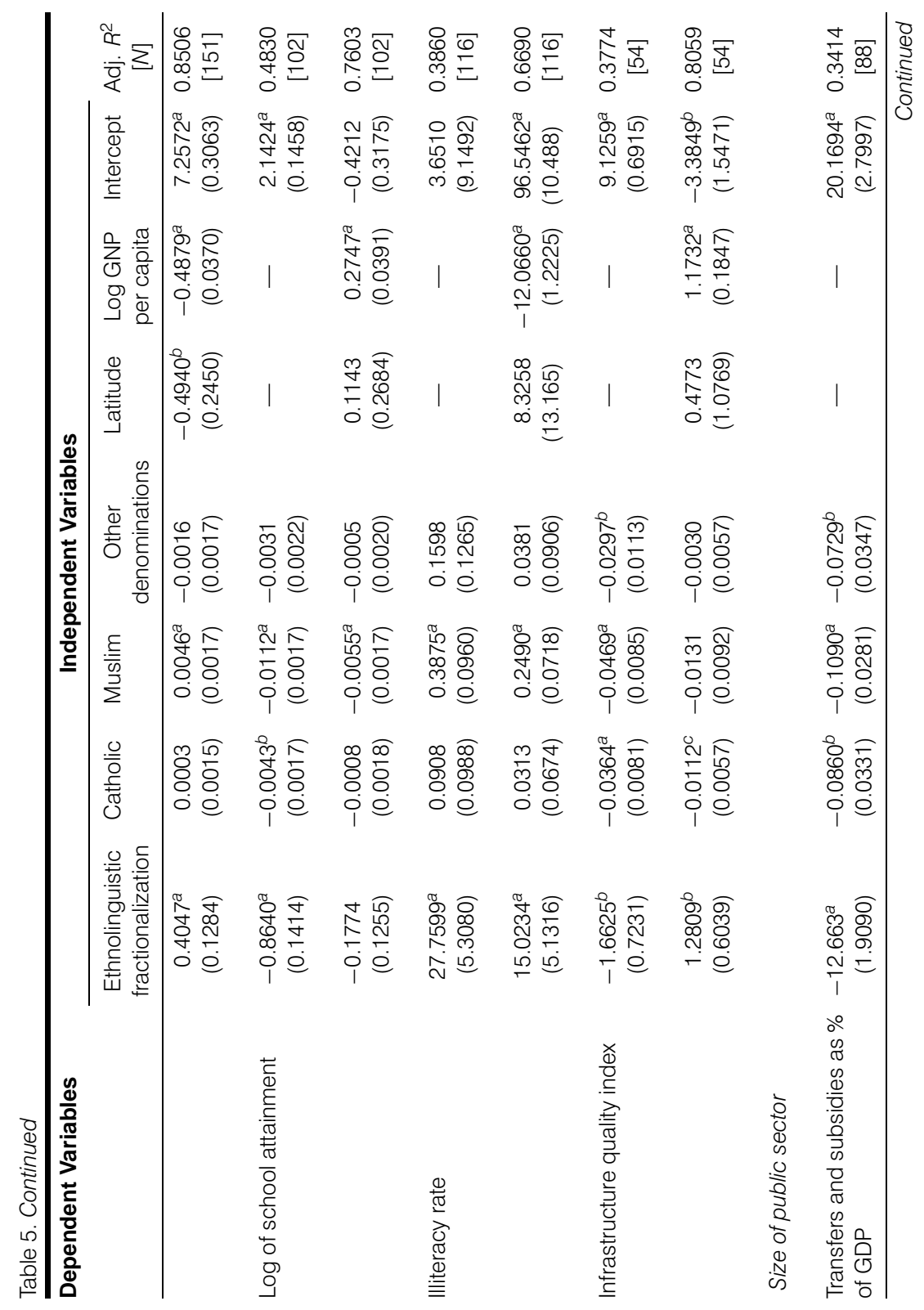


254 The Journal of Law, Economics, \& Organization, V15 N1

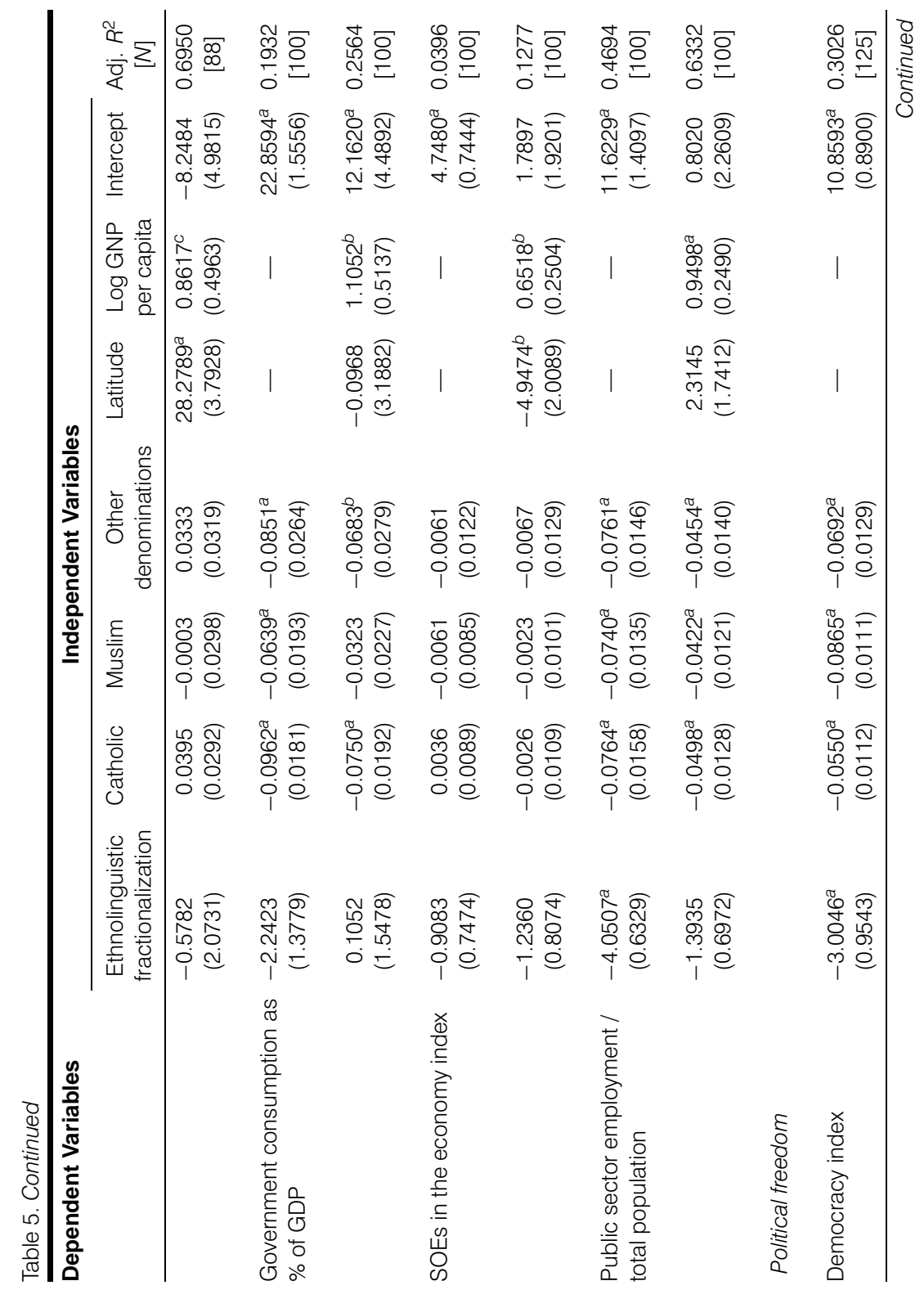




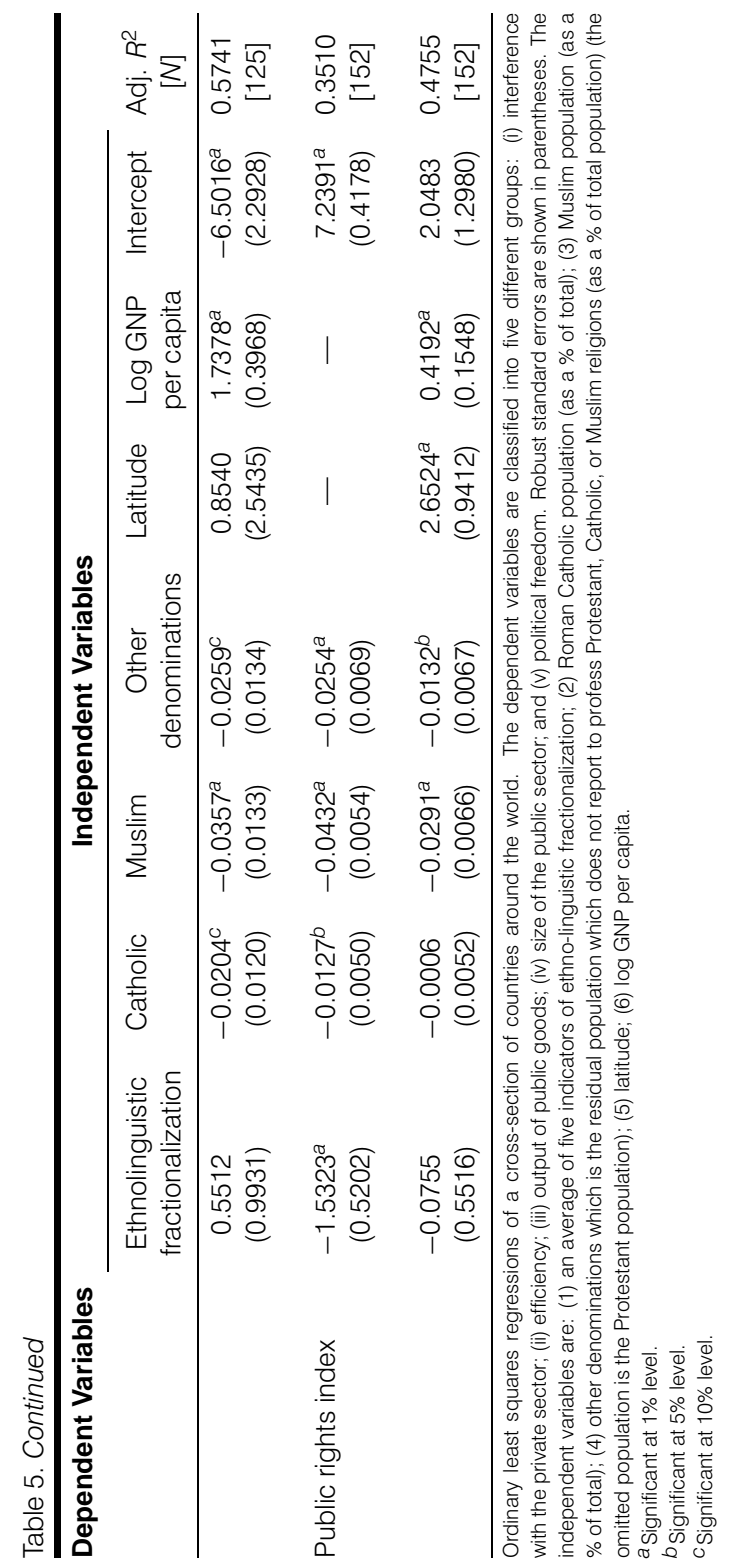


Table 6. Government Performance, Legal Origin, and Religion

Dependent Variables

\section{Independent Variables}

\begin{tabular}{|c|c|c|c|c|c|c|c|c|c|c|c|c|}
\hline & \\
\hline & $\begin{array}{l}\text { Ethnolinguistic } \\
\text { fractionalization }\end{array}$ & $\begin{array}{l}\text { Socialist } \\
\text { legal origin }\end{array}$ & $\begin{array}{l}\text { French } \\
\text { legal origin }\end{array}$ & $\begin{array}{l}\text { German } \\
\text { legal origin }\end{array}$ & $\begin{array}{l}\text { Scandinavian } \\
\text { legal origin }\end{array}$ & Catholic & Muslim & $\begin{array}{l}\text { Other } \\
\text { religions }\end{array}$ & Latitude & $\begin{array}{l}\text { Log GNP } \\
\text { per capita }\end{array}$ & Intercept & $\begin{array}{l}\text { Adj. } R^{2} \\
{[N]}\end{array}$ \\
\hline \multicolumn{13}{|c|}{ Interference with the private sector } \\
\hline \multirow[t]{2}{*}{ Property rights index } & $\begin{array}{r}-0.7013^{b} \\
(0.3041)\end{array}$ & $\begin{array}{r}-1.3894^{a} \\
(0.3932)\end{array}$ & $\begin{array}{r}-0.7900^{a} \\
(0.2730)\end{array}$ & $\begin{array}{l}0.9918^{a} \\
(0.2052)\end{array}$ & $\begin{array}{l}0.9416^{\mathrm{C}} \\
(0.5101)\end{array}$ & $\begin{array}{l}0.0041 \\
(0.0066)\end{array}$ & $\begin{array}{r}-0.0037 \\
(0.0068)\end{array}$ & $\begin{array}{r}-0.0003 \\
(0.0060)\end{array}$ & - & - & $\begin{array}{r}3.9053^{a} \\
(0.5176)\end{array}$ & $\begin{array}{r}0.3557 \\
{[124]}\end{array}$ \\
\hline & $\begin{array}{l}0.3843 \\
(0.2661)\end{array}$ & $\begin{array}{r}-1.2522^{a} \\
(0.3048)\end{array}$ & $\begin{array}{r}-0.6531^{a} \\
(0.1870)\end{array}$ & $\begin{array}{l}0.0519 \\
(0.2383)\end{array}$ & $\begin{array}{r}-0.1921 \\
(0.4238)\end{array}$ & $\begin{array}{c}0.0062 \\
(0.0044)\end{array}$ & $\begin{array}{l}0.0024 \\
(0.0050)\end{array}$ & $\begin{array}{l}0.0049 \\
(0.0044)\end{array}$ & $\begin{array}{l}1.7985^{a} \\
(0.5801)\end{array}$ & $\begin{array}{l}0.3892^{a} \\
(0.0929)\end{array}$ & $\begin{array}{r}-0.0431 \\
(0.7176)\end{array}$ & $\begin{array}{r}0.6408 \\
{[124]}\end{array}$ \\
\hline \multirow[t]{2}{*}{ Business regulation index } & $\begin{array}{r}-1.0988^{a} \\
(0.2759)\end{array}$ & $\begin{array}{r}-1.2348^{a} \\
(0.3420)\end{array}$ & $\begin{array}{r}-0.3404 \\
(0.2277)\end{array}$ & $\begin{array}{r}-0.1500 \\
(0.2375)\end{array}$ & $\begin{array}{c}-0.0095 \\
(0.4170)\end{array}$ & $\begin{array}{r}-0.0004 \\
(0.0053)\end{array}$ & $\begin{array}{r}-0.0034 \\
(0.0055)\end{array}$ & $\begin{array}{l}0.0040 \\
(0.0053)\end{array}$ & - & - & $\begin{array}{r}3.2539^{a} \\
(0.4318)\end{array}$ & $\begin{array}{r}0.2299 \\
{[124]}\end{array}$ \\
\hline & $\begin{array}{r}-0.2661 \\
(0.2479)\end{array}$ & $\begin{array}{l}-0.8376^{a} \\
(0.2812)\end{array}$ & $\begin{array}{r}-0.2491 \\
(0.1633)\end{array}$ & $\begin{array}{r}-0.9027^{a} \\
(0.1810)\end{array}$ & $\begin{array}{r}-0.6382 \\
(0.4003)\end{array}$ & $\begin{array}{l}0.0030 \\
(0.0043)\end{array}$ & $\begin{array}{l}0.0039 \\
(0.0046)\end{array}$ & $\begin{array}{r}0.0084^{C} \\
(0.0043)\end{array}$ & $\begin{array}{l}0.1859 \\
(0.5908)\end{array}$ & $\begin{array}{l}0.4570^{a} \\
(0.0914)\end{array}$ & $\begin{array}{r}-0.7207 \\
(0.6776)\end{array}$ & $\begin{array}{r}0.5479 \\
{[124]}\end{array}$ \\
\hline $\begin{array}{l}\text { Top marginal tax rate in } \\
1994\end{array}$ & $\begin{array}{l}1.4378 \\
(5.7018)\end{array}$ & $\begin{array}{l}14.9193^{a} \\
(4.6331)\end{array}$ & $\begin{array}{l}6.5827 \\
(4.4391)\end{array}$ & $\begin{array}{l}10.5544^{C} \\
(5.8712)\end{array}$ & $\begin{array}{l}11.1248 \\
(9.6287)\end{array}$ & $\begin{array}{r}-0.1657 \\
(0.1233)\end{array}$ & $\begin{array}{r}-0.0586 \\
(0.1103)\end{array}$ & $\begin{array}{r}-0.0791 \\
(0.1152)\end{array}$ & - & - & $\begin{array}{l}45.8541^{a} \\
(10.121)\end{array}$ & $\begin{array}{c}0.2039 \\
{[79]}\end{array}$ \\
\hline 1994 & $\begin{array}{l}13.9829^{b} \\
(6.5626)\end{array}$ & $\begin{array}{l}13.9606^{b} \\
(6.0011)\end{array}$ & $\begin{array}{l}7.6698^{C} \\
(4.1466)\end{array}$ & $\begin{array}{c}6.4841 \\
(5.9912)\end{array}$ & $\begin{array}{l}7.1961 \\
(7.6966)\end{array}$ & $\begin{array}{r}-0.0962 \\
(0.0908)\end{array}$ & $\begin{array}{c}0.0159 \\
(0.0918)\end{array}$ & $\begin{array}{r}-0.0215 \\
(0.1023)\end{array}$ & $\begin{array}{l}16.8895 \\
(10.964)\end{array}$ & $\begin{array}{c}2.9196 \\
(1.8765)\end{array}$ & $\begin{array}{r}8.9102 \\
(15.468)\end{array}$ & $\begin{array}{c}0.3229 \\
{[79]}\end{array}$ \\
\hline \multicolumn{13}{|l|}{ Efficiency } \\
\hline Corruption & $\begin{array}{r}-2.2008^{a} \\
(0.8273)\end{array}$ & $\begin{array}{r}-0.1559 \\
(0.6641)\end{array}$ & $\begin{array}{r}-0.5023 \\
(0.5516)\end{array}$ & $\begin{array}{c}1.4193 \\
(0.8955)\end{array}$ & $\begin{array}{c}2.6055 \\
(1.6767)\end{array}$ & $\begin{array}{r}-0.0115 \\
(0.0203)\end{array}$ & $\begin{array}{r}-0.0204 \\
(0.0189)\end{array}$ & $\begin{array}{r}-0.0087 \\
(0.0180)\end{array}$ & - & - & $\begin{array}{c}7.6444^{a} \\
(1.8791)\end{array}$ & $\begin{array}{r}0.3237 \\
{[114]}\end{array}$ \\
\hline
\end{tabular}


Table 6. Continued

Dependent Variables

Independent Variables

\begin{tabular}{|c|c|c|c|c|c|c|c|c|c|c|c|c|}
\hline & $\begin{array}{l}\text { Ethnolinguistic } \\
\text { fractionalization }\end{array}$ & $\begin{array}{c}\text { Socialist } \\
\text { legal origin }\end{array}$ & $\begin{array}{c}\text { French } \\
\text { legal origin }\end{array}$ & $\begin{array}{l}\text { German } \\
\text { legal origin }\end{array}$ & $\begin{array}{c}\text { Scandinavian } \\
\text { legal origin }\end{array}$ & Catholic & Muslim & $\begin{array}{l}\text { Other } \\
\text { religions }\end{array}$ & Latitude & $\begin{array}{l}\text { Log GNP } \\
\text { per capita }\end{array}$ & Intercept & $\begin{array}{c}\text { Adj. } R^{2} \\
{[N]}\end{array}$ \\
\hline & $\begin{array}{c}0.5909 \\
(0.8821)\end{array}$ & $\begin{array}{r}-0.0732 \\
(0.5916)\end{array}$ & $\begin{array}{r}-0.2364 \\
(0.4404)\end{array}$ & $\begin{array}{r}-0.0929 \\
(0.5779)\end{array}$ & $\begin{array}{c}0.9132 \\
(1.1987)\end{array}$ & $\begin{array}{l}0.0001 \\
(0.0149)\end{array}$ & $\begin{array}{r}-0.0014 \\
(0.0143)\end{array}$ & $\begin{array}{l}0.0067 \\
(0.0134)\end{array}$ & $\begin{array}{r}4.3158^{a} \\
(1.4094)\end{array}$ & $\begin{array}{c}0.7725^{a} \\
(0.1984)\end{array}$ & $\begin{array}{r}-1.3701 \\
(2.1381)\end{array}$ & $\begin{array}{c}0.5818 \\
{[114]}\end{array}$ \\
\hline \multirow[t]{2}{*}{ Bureaucratic delays } & $\begin{array}{r}-2.0774^{a} \\
(0.6394)\end{array}$ & $\begin{array}{r}-2.0465^{a} \\
(0.5910)\end{array}$ & $\begin{array}{r}-1.0801^{a} \\
(0.4012)\end{array}$ & $\begin{array}{l}0.1384 \\
(0.4674)\end{array}$ & $\begin{array}{c}-2.3447^{a} \\
(0.8156)\end{array}$ & $\begin{array}{r}-0.0350^{a} \\
(0.0107)\end{array}$ & $\begin{array}{r}-0.0442^{a} \\
(0.0105)\end{array}$ & $\begin{array}{r}-0.0322^{a} \\
(0.0106)\end{array}$ & - & - & $\begin{array}{l}9.1862^{a} \\
(0.8196)\end{array}$ & $\begin{array}{c}0.6430 \\
{[54]}\end{array}$ \\
\hline & $\begin{array}{r}-0.2225 \\
(0.6107)\end{array}$ & $\begin{array}{r}-0.7470 \\
(0.6091)\end{array}$ & $\begin{array}{r}-0.5488^{C} \\
(0.3206)\end{array}$ & $\begin{array}{r}-0.0030 \\
(0.3308)\end{array}$ & $\begin{array}{r}-1.6180^{b} \\
(0.6397)\end{array}$ & $\begin{array}{r}-0.0224^{b} \\
(0.0090)\end{array}$ & $\begin{array}{r}-0.0264^{b} \\
(0.0107)\end{array}$ & $\begin{array}{r}-0.0165^{C} \\
(0.0089)\end{array}$ & $\begin{array}{c}0.1007 \\
(1.1806)\end{array}$ & $\begin{array}{c}0.6362^{a} \\
(0.2220)\end{array}$ & $\begin{array}{l}2.0056 \\
(2.0288)\end{array}$ & $\begin{array}{c}0.7885 \\
{[54]}\end{array}$ \\
\hline \multirow[t]{2}{*}{ Tax compliance } & $\begin{array}{r}-1.4229^{b} \\
(0.5966)\end{array}$ & $\begin{array}{r}-1.9495^{a} \\
(0.3106)\end{array}$ & $\begin{array}{r}-1.4780^{a} \\
(0.3036)\end{array}$ & $\begin{array}{r}-0.5448^{\mathrm{C}} \\
(0.3203)\end{array}$ & $\begin{array}{r}-1.4599^{b} \\
(0.5636)\end{array}$ & $\begin{array}{r}-0.0090 \\
(0.0079)\end{array}$ & $\begin{array}{r}-0.0038 \\
(0.0086)\end{array}$ & $\begin{array}{l}0.0071 \\
(0.0075)\end{array}$ & - & - & $\begin{array}{c}5.0747^{a} \\
(0.6132)\end{array}$ & $\begin{array}{c}0.5201 \\
{[48]}\end{array}$ \\
\hline & $\begin{array}{r}-0.6969 \\
(0.6030)\end{array}$ & $\begin{array}{r}-0.9764^{b} \\
(0.4741)\end{array}$ & $\begin{array}{r}-1.0886^{a} \\
(0.2587)\end{array}$ & $\begin{array}{c}-0.5867^{b} \\
(0.2714)\end{array}$ & $\begin{array}{r}-1.0331^{C} \\
(0.5601)\end{array}$ & $\begin{array}{r}-0.0056 \\
(0.0070)\end{array}$ & $\begin{array}{l}0.0054 \\
(0.0087)\end{array}$ & $\begin{array}{r}-0.0013 \\
(0.0074)\end{array}$ & $\begin{array}{r}-1.0134 \\
(0.7531)\end{array}$ & $\begin{array}{l}0.4711^{a} \\
(0.1430)\end{array}$ & $\begin{array}{c}0.7286 \\
(1.5921)\end{array}$ & $\begin{array}{c}0.6283 \\
{[48]}\end{array}$ \\
\hline \multirow[t]{2}{*}{$\begin{array}{l}\text { Avg. government wages / } \\
\text { GNP per capita }\end{array}$} & $\begin{array}{c}0.9124 \\
(0.8598)\end{array}$ & $\begin{array}{r}-0.7845^{a} \\
(0.2731)\end{array}$ & $\begin{array}{l}1.2156^{a} \\
(0.3086)\end{array}$ & $\begin{array}{r}-0.0643 \\
(0.2873)\end{array}$ & $\begin{array}{r}-0.3760 \\
(0.6509)\end{array}$ & $\begin{array}{r}-0.0037 \\
(0.0074)\end{array}$ & $\begin{array}{c}0.0045 \\
(0.0077)\end{array}$ & $\begin{array}{c}0.0058 \\
(0.0089)\end{array}$ & - & - & $\begin{array}{l}1.3803^{C} \\
(0.7166)\end{array}$ & $\begin{array}{c}0.5010 \\
{[47]}\end{array}$ \\
\hline & $\begin{array}{c}0.5150 \\
(0.7203)\end{array}$ & $\begin{array}{r}-1.8937^{a} \\
(0.5136)\end{array}$ & $\begin{array}{l}1.1686^{a} \\
(0.3380)\end{array}$ & $\begin{array}{l}0.4324 \\
(0.3049)\end{array}$ & $\begin{array}{r}-1.3567^{\mathrm{C}} \\
(0.7655)\end{array}$ & $\begin{array}{r}-0.0200^{b} \\
(0.0087)\end{array}$ & $\begin{array}{r}-0.0204^{C} \\
(0.0101)\end{array}$ & $\begin{array}{r}-0.0091 \\
(0.0103)\end{array}$ & $\begin{array}{l}2.4471^{b} \\
(0.9250)\end{array}$ & $\begin{array}{r}-0.8031^{a} \\
(0.1872)\end{array}$ & $\begin{array}{r}8.5803^{a} \\
(1.8527)\end{array}$ & $\begin{array}{c}0.6672 \\
{[47]}\end{array}$ \\
\hline \multicolumn{13}{|l|}{ Output of public goods } \\
\hline Log of infant mortality & $\begin{array}{c}1.2610^{a} \\
(0.1805)\end{array}$ & $\begin{array}{c}0.5676^{b} \\
(0.2751)\end{array}$ & $\begin{array}{c}0.4244^{a} \\
(0.1571)\end{array}$ & $\begin{array}{c}-0.7441^{a} \\
(0.2692)\end{array}$ & $\begin{array}{r}-1.4558^{a} \\
(0.2510)\end{array}$ & $\begin{array}{r}-0.0056 \\
(0.0038)\end{array}$ & $\begin{array}{c}0.0045 \\
(0.0033)\end{array}$ & $\begin{array}{r}-0.0036 \\
(0.0038)\end{array}$ & - & - & $\begin{array}{c}3.4664^{a} \\
(0.2827)\end{array}$ & $\begin{array}{c}0.5255 \\
{[151]}\end{array}$ \\
\hline
\end{tabular}


Table 6. Continued

Independent Variables

Dependent Variables

Ethnolinguistic Socialist French German Scandinavian Catholic Muslim Other Latitude Log GNP Intercept Adj. $R^{2}$ fractionalization legal origin legal origin legal origin legal origin

\begin{tabular}{|c|c|c|c|c|c|c|c|c|c|c|c|c|}
\hline & fractionalization & legal origin & legal origin & legal origin & legal origin & & & religions & & per capita & & {$[N]$} \\
\hline & $0.4020^{a}$ & 0.1408 & $0.2609^{a}$ & 0.0983 & $-0.4970^{b}$ & $-0.0053^{b}$ & 0.0000 & $-0.0053^{b}$ & -0.4252 & $-0.4754^{a}$ & $7.4267^{a}$ & 0.8637 \\
\hline & $(0.1300)$ & $(0.1727)$ & $(0.0794)$ & $(0.1268)$ & $(0.2120)$ & $(0.0025)$ & $(0.0024)$ & $(0.0025)$ & $(0.2836)$ & $(0.0415)$ & $(0.3683)$ & [151] \\
\hline \multirow[t]{4}{*}{ Log of school attainment } & $-0.7840^{a}$ & $0.3276^{a}$ & $-0.2593^{b}$ & 0.1521 & 0.3324 & 0.0004 & $-0.0069^{b}$ & -0.0008 & - & - & $1.8889^{a}$ & 0.5322 \\
\hline & $(0.1499)$ & $(0.1058)$ & $(0.1065)$ & $(0.1416)$ & $(0.2476)$ & $(0.0032)$ & $(0.0031)$ & $(0.0034)$ & & & $(0.2801)$ & [102] \\
\hline & -0.1821 & $0.4050^{a}$ & $-0.1914^{a}$ & $-0.2251^{b}$ & -0.1966 & -0.0000 & -0.0045 & 0.0011 & 0.0249 & $0.2942^{a}$ & -0.4628 & 0.7974 \\
\hline & $(0.1199)$ & $(0.0964)$ & $(0.0643)$ & $(0.0916)$ & $(0.1932)$ & $(0.0025)$ & $(0.0023)$ & $(0.0028)$ & $(0.2611)$ & $(0.0389)$ & $(0.3354)$ & [102] \\
\hline \multirow[t]{4}{*}{ Illiteracy rate } & $27.0753^{a}$ & 7.7474 & $8.9148^{C}$ & $-12.881^{b}$ & - & -0.0490 & $0.2737^{a}$ & 0.0884 & - & - & 8.5013 & 0.4226 \\
\hline & $(5.4717)$ & (10.479) & (4.9304) & $(6.1284)$ & & $(0.1245)$ & $(0.1229)$ & $(0.1544)$ & & & (9.7099) & [116] \\
\hline & $12.5505^{b}$ & -10.404 & $6.8149^{C}$ & -5.0399 & - & -0.0497 & $0.1873^{b}$ & 0.0537 & 5.7156 & $-12.2460^{a}$ & $99.6097^{a}$ & 0.6878 \\
\hline & $(5.0585)$ & $(9.8843)$ & (3.5124) & $(4.6052)$ & & $(0.0874)$ & $(0.0867)$ & $(0.1077)$ & (12.903) & $(1.3433)$ & $(10.965)$ & [116] \\
\hline \multirow[t]{4}{*}{ Infrastructure quality index } & $-2.6254^{a}$ & $-3.3972^{a}$ & $-1.1956^{a}$ & 0.4224 & $-3.1489^{a}$ & $-0.0482^{a}$ & $-0.0587^{a}$ & $-0.0458^{a}$ & - & - & $11.5389^{a}$ & 0.6711 \\
\hline & (0.6199) & $(0.7994)$ & (0.4079) & $(0.6621)$ & $(1.1454)$ & $(0.0131)$ & $(0.0126)$ & $(0.0127)$ & & & $(1.1681)$ & [54] \\
\hline & 0.2361 & $-1.8375^{b}$ & -0.3693 & 0.2153 & $-2.2470^{a}$ & $-0.0284^{a}$ & $-0.0328^{a}$ & $-0.0204^{b}$ & 1.6779 & $0.7915^{a}$ & 1.4527 & 0.8647 \\
\hline & $(0.5079)$ & $(0.7730)$ & $(0.2823)$ & $(0.4692)$ & $(0.7525)$ & $(0.0091)$ & $(0.0109)$ & $(0.0087)$ & $(1.0857)$ & $(0.2180)$ & (1.9191) & [54] \\
\hline \multicolumn{13}{|l|}{ Size of public sector } \\
\hline \multicolumn{2}{|c|}{ Transfers and subsidies as $\%-10.429^{a}$} & $10.0018^{a}$ & -1.6490 & 0.7443 & 5.8750 & -0.0259 & -0.0514 & -0.0422 & - & - & $15.2889^{b}$ & 0.4266 \\
\hline of GDP & (2.2704) & (2.7618) & (2.1624) & (3.1120) & (6.5351) & $(0.0782)$ & $(0.0697)$ & $(0.0682)$ & & & $(6.4337)$ & [88] \\
\hline
\end{tabular}


Table 6. Continued

Dependent Variables

Independent Variables

\begin{tabular}{|c|c|c|c|c|c|c|c|c|c|c|c|c|}
\hline & $\begin{array}{l}\text { Ethnolinguistic } \\
\text { fractionalization }\end{array}$ & $\begin{array}{c}\text { Socialist } \\
\text { legal origin }\end{array}$ & $\begin{array}{c}\text { French } \\
\text { legal origin }\end{array}$ & $\begin{array}{l}\text { German } \\
\text { legal origin }\end{array}$ & $\begin{array}{l}\text { Scandinavian } \\
\text { legal origin }\end{array}$ & Catholic & Muslim & $\begin{array}{c}\text { Other } \\
\text { religions }\end{array}$ & Latitude & $\begin{array}{l}\text { Log GNP } \\
\text { per capita }\end{array}$ & Intercept & $\begin{array}{l}\text { Adj. } R^{2} \\
{[N]}\end{array}$ \\
\hline & $\begin{array}{r}-0.3402 \\
(2.0479)\end{array}$ & $\begin{array}{l}6.1352^{b} \\
(3.0242)\end{array}$ & $\begin{array}{c}0.3590 \\
(1.2501)\end{array}$ & $\begin{array}{r}-3.6369 \\
(2.3440)\end{array}$ & $\begin{array}{r}-0.5825 \\
(4.3890)\end{array}$ & $\begin{array}{l}0.0218 \\
(0.0415)\end{array}$ & $\begin{array}{r}-0.0087 \\
(0.0393)\end{array}$ & $\begin{array}{l}0.0157 \\
(0.0394)\end{array}$ & $\begin{array}{r}24.1427^{a} \\
(3.9456)\end{array}$ & $\begin{array}{l}1.5940^{a} \\
(0.5324)\end{array}$ & $\begin{array}{r}-11.3810^{b} \\
(5.3205)\end{array}$ & $\begin{array}{c}0.7297 \\
{[88]}\end{array}$ \\
\hline \multirow[t]{2}{*}{$\begin{array}{l}\text { Government consumption as } \\
\% \text { of GDP }\end{array}$} & $\begin{array}{r}-3.0761^{\mathrm{C}} \\
(1.5586)\end{array}$ & $\begin{array}{r}-5.0546^{a} \\
(1.5113)\end{array}$ & $\begin{array}{r}-0.7166 \\
(1.1828)\end{array}$ & $\begin{array}{r}-1.7008 \\
(1.9574)\end{array}$ & $\begin{array}{c}0.2411 \\
(3.2478)\end{array}$ & $\begin{array}{r}-0.0843^{b} \\
(0.0332)\end{array}$ & $\begin{array}{r}-0.0558^{\mathrm{C}} \\
(0.0303)\end{array}$ & $\begin{array}{r}-0.0714^{\mathrm{C}} \\
(0.0383)\end{array}$ & - & - & $\begin{array}{r}22.7980^{a} \\
(2.6229)\end{array}$ & $\begin{array}{r}0.2316 \\
{[100]}\end{array}$ \\
\hline & $\begin{array}{r}-0.4569 \\
(1.5940)\end{array}$ & $\begin{array}{r}-5.4747^{a} \\
(1.4245)\end{array}$ & $\begin{array}{r}-0.4151 \\
(1.0868)\end{array}$ & $\begin{array}{r}-3.4240^{\mathrm{C}} \\
(2.0800)\end{array}$ & $\begin{array}{r}-1.4461 \\
(3.0986)\end{array}$ & $\begin{array}{r}-0.0706^{b} \\
(0.0312)\end{array}$ & $\begin{array}{r}-0.0339 \\
(0.0315)\end{array}$ & $\begin{array}{r}-0.0576 \\
(0.0370)\end{array}$ & $\begin{array}{l}3.1099 \\
(3.4085)\end{array}$ & $\begin{array}{l}0.9854^{C} \\
(0.5706)\end{array}$ & $\begin{array}{r}12.5943^{b} \\
(5.3128)\end{array}$ & $\begin{array}{r}0.3074 \\
{[100]}\end{array}$ \\
\hline \multirow[t]{2}{*}{ SOEs in the economy index } & $\begin{array}{r}-1.7574^{b} \\
(0.7749)\end{array}$ & $\begin{array}{r}-5.0152^{a} \\
(0.5294)\end{array}$ & $\begin{array}{l}0.0354 \\
(0.5594)\end{array}$ & $\begin{array}{l}0.3548 \\
(1.0483)\end{array}$ & $\begin{array}{r}-2.0452 \\
(1.4665)\end{array}$ & $\begin{array}{r}-0.0098 \\
(0.0180)\end{array}$ & $\begin{array}{r}-0.0189 \\
(0.0161)\end{array}$ & $\begin{array}{r}-0.0091 \\
(0.0177)\end{array}$ & - & - & $\begin{array}{r}6.2642^{a} \\
(1.5382)\end{array}$ & $\begin{array}{r}0.2450 \\
{[100]}\end{array}$ \\
\hline & $\begin{array}{r}-1.5762^{\mathrm{C}} \\
(0.8258)\end{array}$ & $\begin{array}{r}-4.5385^{a} \\
(0.6178)\end{array}$ & $\begin{array}{r}-0.0379 \\
(0.5697)\end{array}$ & $\begin{array}{c}0.0848 \\
(1.0463)\end{array}$ & $\begin{array}{r}-1.9666 \\
(1.3848)\end{array}$ & $\begin{array}{r}-0.0094 \\
(0.0184)\end{array}$ & $\begin{array}{r}-0.0137 \\
(0.0165)\end{array}$ & $\begin{array}{r}-0.0089 \\
(0.0181)\end{array}$ & $\begin{array}{r}-1.8264 \\
(1.9240)\end{array}$ & $\begin{array}{l}0.3692 \\
(0.2416)\end{array}$ & $\begin{array}{l}3.8933 \\
(2.2718)\end{array}$ & $\begin{array}{r}0.2648 \\
{[100]}\end{array}$ \\
\hline \multirow[t]{2}{*}{$\begin{array}{l}\text { Public sector employment / } \\
\text { total population }\end{array}$} & $\begin{array}{r}-3.3400^{a} \\
(0.6646)\end{array}$ & $\begin{array}{r}-0.3848 \\
(0.9318)\end{array}$ & $\begin{array}{r}-1.1109^{b} \\
(0.4833)\end{array}$ & $\begin{array}{r}-0.6880 \\
(0.9384)\end{array}$ & $\begin{array}{r}8.0477^{a} \\
(1.8996)\end{array}$ & $\begin{array}{r}-0.0075 \\
(0.0167)\end{array}$ & $\begin{array}{r}-0.0149 \\
(0.0143)\end{array}$ & $\begin{array}{r}-0.0147 \\
(0.0159)\end{array}$ & - & - & $\begin{array}{r}6.2029^{a} \\
(1.4515)\end{array}$ & $\begin{array}{r}0.5978 \\
{[100]}\end{array}$ \\
\hline & $\begin{array}{r}-0.9215 \\
(0.5762)\end{array}$ & $\begin{array}{l}0.6805 \\
(0.8417)\end{array}$ & $\begin{array}{r}-0.7417^{\mathrm{C}} \\
(0.3940)\end{array}$ & $\begin{array}{r}-2.5817^{b} \\
(1.6003)\end{array}$ & $\begin{array}{l}6.9815^{a} \\
(1.6004)\end{array}$ & $\begin{array}{l}0.0042 \\
(0.0124)\end{array}$ & $\begin{array}{l}0.0068 \\
(0.0117)\end{array}$ & $\begin{array}{c}0.0038 \\
(0.0141)\end{array}$ & $\begin{array}{r}-0.1045 \\
(2.0524)\end{array}$ & $\begin{array}{l}1.2912^{a} \\
(0.2835)\end{array}$ & $\begin{array}{r}-5.3766^{b} \\
(2.3324)\end{array}$ & $\begin{array}{r}0.7657 \\
{[100]}\end{array}$ \\
\hline \multicolumn{13}{|l|}{ Political freedom } \\
\hline Democracy index & $\begin{array}{r}-3.5236^{a} \\
(1.1404)\end{array}$ & $\begin{array}{r}-4.9840^{a} \\
(0.8777)\end{array}$ & $\begin{array}{r}-2.5819^{a} \\
(0.8671)\end{array}$ & $\begin{array}{c}0.4810 \\
(1.5157)\end{array}$ & $\begin{array}{l}1.5197 \\
(2.0742)\end{array}$ & $\begin{array}{r}-0.0081 \\
(0.0265)\end{array}$ & $\begin{array}{r}-0.0464 \\
(0.0247)\end{array}$ & $\begin{array}{r}-0.0302 \\
(0.0250)\end{array}$ & - & - & $\begin{array}{l}9.0226^{a} \\
(2.3289)\end{array}$ & $\begin{array}{r}0.4262 \\
{[125]}\end{array}$ \\
\hline
\end{tabular}


Ordinary least squares regressions of a cross-section of countries around the world. The dependent variables are classified into five different groups: (i) interference with the private sector; (ii) public sector efficiency; (iii) output of public goods; (iv) size of public sector; and (v) political freedom. Robust standard errors are shown in parentheses. The independent variables are. Catholic population (as a \% of total); (4) Muslim population (as a \% of total); (5) residual population (as a \% of total); (5) other denominations which is the residual population which does not report to profess Protestant, Catholic, or Muslim religions (as a \% of total population) (the omitted population is the Protestant population); (6) latitude; (7) log GNP per capita.

asignificant at $1 \%$ level.

${ }^{b}$ Significant at $5 \%$ level.

${ }^{\mathrm{C}}$ Significant at $10 \%$ level.

\begin{tabular}{|c|c|c|c|c|c|c|c|c|c|c|c|}
\hline $\begin{array}{l}\text { Ethnolinguistic } \\
\text { fractionalization }\end{array}$ & $\begin{array}{c}\text { Socialist } \\
\text { legal origin }\end{array}$ & $\begin{array}{c}\text { French } \\
\text { legal origin }\end{array}$ & $\begin{array}{l}\text { German } \\
\text { legal origin }\end{array}$ & $\begin{array}{l}\text { Scandinavian } \\
\text { legal origin }\end{array}$ & Catholic & Muslim & $\begin{array}{l}\text { Other } \\
\text { religions }\end{array}$ & Latitude & $\begin{array}{l}\text { Log GNP } \\
\text { per capita }\end{array}$ & Intercept & $\begin{array}{c}\text { Adj. } R^{2} \\
{[N]}\end{array}$ \\
\hline $\begin{array}{c}-0.2370 \\
(1.0095)\end{array}$ & $\begin{array}{r}-4.2093^{a} \\
(0.9607)\end{array}$ & $\begin{array}{c}-2.1704^{a} \\
(0.6412)\end{array}$ & $\begin{array}{c}-2.4051^{b} \\
(1.1647)\end{array}$ & $\begin{array}{r}-1.2381 \\
(1.6795)\end{array}$ & $\begin{array}{c}0.0031 \\
(0.0217)\end{array}$ & $\begin{array}{r}-0.0203 \\
(0.0212)\end{array}$ & $\begin{array}{r}-0.0085 \\
(0.0216)\end{array}$ & $\begin{array}{c}3.2446 \\
(2.6246)\end{array}$ & $\begin{array}{l}1.4940^{a} \\
(0.3303)\end{array}$ & $\begin{array}{r}-5.1883^{\mathrm{C}} \\
(2.9477)\end{array}$ & $\begin{array}{r}0.6511 \\
{[125]}\end{array}$ \\
\hline $\begin{array}{r}-1.5088^{a} \\
(0.5672)\end{array}$ & $\begin{array}{c}-1.0721 \\
(0.7895)\end{array}$ & $\begin{array}{r}-0.7744^{C} \\
(0.4081)\end{array}$ & $\begin{array}{l}0.9945^{a} \\
(0.3667)\end{array}$ & $\begin{array}{c}0.6585 \\
(0.6596)\end{array}$ & $\begin{array}{r}-0.0006 \\
(0.0092)\end{array}$ & $\begin{array}{r}-0.0327^{a} \\
(0.0090)\end{array}$ & $\begin{array}{r}-0.0154 \\
(0.0096)\end{array}$ & - & - & $\begin{array}{c}6.5948^{a} \\
(0.7466)\end{array}$ & $\begin{array}{r}0.3792 \\
{[152]}\end{array}$ \\
\hline $\begin{array}{r}-0.2595 \\
(0.5705)\end{array}$ & $\begin{array}{r}-1.3386^{C} \\
(0.6793)\end{array}$ & $\begin{array}{r}-0.7521^{C} \\
(0.3711)\end{array}$ & $\begin{array}{r}-0.4058 \\
(0.4524)\end{array}$ & $\begin{array}{r}-1.5218^{b} \\
(0.6528)\end{array}$ & $\begin{array}{r}-0.0003 \\
(0.0084)\end{array}$ & $\begin{array}{r}-0.0305^{a} \\
(0.0086)\end{array}$ & $\begin{array}{r}-0.0137 \\
(0.0087)\end{array}$ & $\begin{array}{r}3.9678^{a} \\
(1.0809)\end{array}$ & $\begin{array}{c}0.3138^{C} \\
(0.1631)\end{array}$ & $\begin{array}{l}2.9411^{b} \\
(1.4209)\end{array}$ & $\begin{array}{r}0.5005 \\
{[152]}\end{array}$ \\
\hline
\end{tabular}


theory would suggest. Alternatively these results may mean that people in high EF countries are less productive, perhaps because of private rent seeking and warfare, and that low income in turn adversely influences government. Because the first interpretation seems to us to be more straightforward, we interpret the EF evidence as supporting the political theories of institutions. ${ }^{13}$

\subsection{Legal Origin}

The regressions in Table 4 also assess the influence of legal origin on government performance. To begin, the results of the effects of the socialist legal origin are exactly as predicted by the political theory. Compared to those in common law countries, and even controlling for per capita income, latitude, and EF, government in countries of socialist legal origin are more interventionist across the board (have worse protection of property rights, more intrusive regulation, and higher tax rates) as well as being less efficient (lower score on bureaucratic delays and tax compliance, though not on corruption). Of interest, they have lower relative wages of public sector employees. Socialist origin countries have higher infant mortality, though not controlling for how poor they are, and poorer infrastructure quality, even controlling for per capita income. However, they do very well on school attainment, especially controlling for how poor they are-some evidence that their egalitarianism or militarism benefits education. Turning to the size of government, socialist origin countries have sharply higher transfers and subsidies and more state enterprises, but also lower government consumption, than common law countries ceteris paribus. In general, then, we see that socialist law is associated with more interventionism, less efficiency, bigger government transfers, and less democracy—consistent with the obvious political story that socialist policies serve to enhance the power of the State.

The results on the French legal origin are equally striking. Compared to common law countries, French origin countries are sharply more interventionist (have higher top rates, less secure property rights, and worse regulation). They also have less efficient governments, as measured by bureaucratic delays and tax compliance, though not the corruption score. French origin countries pay relatively higher wages to bureaucrats than common law countries do, though this does not buy them greater government efficiency. French origin countries fall behind common law countries in public good provision: they have higher infant mortality, lower school attainment, higher illiteracy rates, and lower infrastructure quality. There is not much evidence of a difference in the pattern of government spending, except that French origin countries have lower public employment. Finally, French origin countries score worse on our democracy measures than the common law countries. Most of these results hold both with and without per capita income and latitude controls. As predicted by the political theory then, the state-building intent incorporated into the design of the French legal system translates, many decades later, into significantly

13. EF may reduce productivity because it undermines human capital accumulation. To the extent that $\mathrm{EF}$ does that through undermining public education, however, the direct effect is on the government institution of public education rather than on productivity. 
more interventionist and less efficient government, less political freedom, and evidently less provision of basic public goods.

The results on the German legal origin suggest that these countries are rather similar to those of common law origin, controlling for income and latitude. These controls are particularly important because German origin countries are generally located in central Europe and East Asia and tend to be relatively rich. Finally, compared to common law countries, Scandinavian origin countries are sharply more interventionist (in fact, the pattern of coefficients here is similar to that for socialist countries), though-with a notable exception of lower tax compliance- they do not have less efficient governments. Scandinavian origin countries also tend to have better public goods and higher public spending than common law countries. Controlling for per capita income and latitude reduces the difference, although in the area of public employment, the Scandinavian origin countries are out on a limb, even controlling for income. These results point to important differences between civil law countries of different origins. In particular, the German and Scandinavian evidence-while consistent with the political theory of institutions - is not nearly as striking as that for countries using French law.

The contrast between the socialist, common law, and French origins, however, is very significant and persistent across the variety of measures. Governments in the socialist law countries are the most antimarket, and those in the common law countries the most promarket, with governments in French origin countries in the middle. The fact that this political heritage matters so much for government performance supports the political theory of institutions, especially when combined with the evidence on the importance of EF.

\subsection{Religious Affiliation}

Table 5 reports the effects of religious affiliations on government performance. Recall that we exclude from the regression the percentage of each country's population reporting to be Protestants. Note first that the results on EF in Table 5 are similar to those in Table 4: EF has a sharp negative influence on government performance, but this influence is captured by the lower per capita income (and closeness to the equator) of high EF countries.

Table 5 reveals that both Catholic and Muslim affiliations of the population are associated with worse government performance, though, as in the case with $\mathrm{EF}$, both of these influences generally become insignificant once per capita income and latitude are controlled for.

Begin with the Catholic affiliation. With the notable exception of the marginal tax rate, Catholic countries are generally more interventionist. Their governments are also less efficient, including more corrupt, but better paid. Catholic countries do worse on public good provision than Protestant countries, they have smaller transfers, government consumption, and public sector employment, and are significantly less democratic. Virtually all of these effects, however, become insignificant once we control for per capita income and latitude. As with EF, there are two stories. The one we find less plausible suggests that Catholics are less productive, and this translates into inferior government. The more plausible 
argument is that the worse-functioning governments of the Catholic countries reduce income, with the result that the adverse effect of the religious affiliation on the quality of government is in part captured by per capita income. ${ }^{14}$

The effect of the Muslim affiliation is generally in the same direction as that of the Catholic affiliation, only stronger. Muslim countries tend to have more interventionist and less efficient, but better paid, governments, although these effects are generally captured by their lower per capita income. There is a remarkably large negative effect of the Muslim affiliation on public good provision, which appears to be strong enough to survive the income and latitude controls. ${ }^{15}$ Muslim countries also tend to have smaller governments (though less so with controls), and be sharply less democratic, even controlling for their poverty. Muslim affiliation thus has a pronounced adverse effect on government performance. If we take the view that the amelioration of this effect when per capita income is included is a consequence of the adverse effects of bad government on income, the problem to be explained only gets bigger.

Finally, we note two side issues that come up in these regressions. First, the results on relative government wages show that both Muslim and Catholic countries pay higher relative government wages than Protestant countries do, but their bureaucracies are still less efficient. The story with government wages and corruption is thus more complicated than the World Bank, inspired by the East Asian experience, would argue (World Bank 1995). In many Catholic and Muslim countries, officials are paid relatively well, but still misuse their power. There are more basic factors determining government efficiency than just the relative pay of the bureaucrats. ${ }^{16}$

Second, compared to Protestant countries, both Catholic and Muslim countries exhibit both poor government performance and low tax rates combined with small government transfers and consumption. This evidence, as well as all the other evidence we have presented, seems squarely inconsistent with the idea that a good government is a small government. Rather, poorly functioning governments tend to be relatively small, and collect fewer taxes, whereas wellfunctioning governments tend to be much larger, presumably at least in part with the consent of the governed. This view is consistent with the finding that the one activity that poorly functioning governments do more of is operate state firms - a redistributive rather than wealth-creating function. This view is also consistent with historical research (Brewer, 1988) and with the recent evidence from the postcommunist transition (Johnson, Kaufman, and Shleifer, 1997).

14. As with ethnic fractionalization, particular religious affiliations may adversely affect human capital accumulation, which in turn reduces income. As with EF, one way in which this happens is that religion undermines public education, so the causation is through government.

15. Since we are looking at the outcome of public good provision, as opposed to just government expenditure on it, our evidence is inconsistent with the theory that Catholic or Muslim religions substitute for the lack of public provision of education through their own provision.

16. An alternative interpretation of these findings is that in Catholic and Muslim countries general educational attainment is low, and hence the bureaucrats are relatively overpaid because they are better educated relative to the rest of the population than are the Protestant bureaucrats. 


\subsection{Law or Religion?}

The evidence in Table 5 does not tell us whether the negative influences of Catholic and Muslim affiliations on government performance are a consequence of troubled political history or of culture. We have made a number of a priori arguments suggesting that cultural theories can work through politics, and that a political interpretation of the religious variables may be more appropriate. That is, the use of religion for political purposes in Muslim and Catholic countries, and the destructive competition between Church and State in Catholic countries in particular, may have shaped policies in ways that ended up being quite hostile to market development. It is possible that such politics worked by adversely affecting tolerance, as in Landes (1998), or trust, as in Putnam (1993) and La Porta et al. (1997b), but the heritage that adversely affects government performance seems to be largely political.

However, as we noted earlier, legal origins and religious affiliations are correlated with each other. To understand the facts better, as well as to make further progress in interpreting the evidence, we would like to know which set of variables, if any, wins out in a horse race. As a final step therefore, we run regressions that include $\mathrm{EF}$, legal origins, and religious affiliations in the same specification. Table 6 presents the results.

We can summarize the findings without discussing each regression individually. EF survives as an important determinant of government performance. Moreover, as a general rule, legal origins — particularly socialist and French continue to exert significant adverse influence on government performance, even controlling for religion. Religious variables, however, generally become insignificant. Catholic affiliation loses its statistical significance almost always (exceptions are bureaucratic delays, infrastructure quality, and government consumption), as does the Muslim affiliation (exceptions are bureaucratic delays, school attainment, illiteracy, and infrastructure quality). Statist laws are thus a more robust predictor of poor government performance than interventionist religions.

If we take religion as a proxy for cultural influences on government, and EF and law as proxies for political influences, this evidence provides further support for the political theories. In our data, these political variables provide the most pervasive, and relatively clearly interpretable, influence on government performance.

\subsection{Other Factors}

There are two variables - colonial status and continent-that we have not included in our statistical analysis which arguably qualify as potentially exogenous determinants of government performance, and which are often used in the cross-sectional studies of economic growth. For completeness, we make some comments about these variables.

Several writers measure whether a country is a former colony, and, if so, what country it was a colony of (Barro, 1996b; Treisman, 1997; Hall and

Jones, 1999). The usual justification for using this variable is that the colonizer has transplanted into the colony some of its key institutions, such as religion 
and law, which in turn influenced subsequent development. We already include religion and law as independent variables, and hence measure these possible colonial influences directly rather than indirectly. As important, we have found it difficult to identify the colonial status of particular countries. For example, Barro (1996b) does not classify Hungary, Czechoslovakia, or Italy as former colonies, even though each was at times (at least partially) controlled by the Habsburg empire, and the former two were arguably colonized by the Soviet Union as well. Because of such difficulties, we stick to our more direct measures.

From the theoretical viewpoint, the justification for using continents as determinants of government performance is also problematic. Various writers find slow growth in Latin America and Africa (Barro, 1991; Easterly and Levine, 1997), but the significance of the continent effects is attributed to the omitted institutional factors, such as religion or, as Easterly and Levine (1997) argue directly for Africa, EF. Since we measure the political and cultural influences on performance directly, the case for including the continent effects is weak. We also include latitude in the regressions, which is the one theoretically justified measure of geography. Still, we have rerun our regressions controlling for continents. These controls have predictable effects. The Africa dummy in particular weakens but does not eliminate the effect of EF, and the Latin America dummy weakens but does not eliminate the effects of French laws or Catholicism. Again, we take this evidence to mean not that the continents have an independent influence on government performance, but rather that they serve as proxies for the more fundamental determinants of the quality of government discussed in this article.

\section{Conclusion}

We have set out to examine whether, from the perspective of promoting development, the quality of government across countries varies in systematic ways. We assess the quality of government using proxies for interventionism, public sector efficiency, quality of public good provision, government size, and political freedom. The data show clearly that, using these measures of performance, the quality of governments varies systematically across countries. Rich nations have better governments than poor ones. Ethnolinguistically homogeneous countries have better governments than the heterogeneous ones. Common law countries have better governments than French civil law or socialist law countries. Predominantly Protestant countries have better governments than either predominantly Catholic or predominantly Muslim countries. These results tend to be consistent across the many measures of government performance we used.

These results present clear evidence of systematic influence of historical circumstances, as captured by ethnolinguistic heterogeneity, legal origins, and religion, on government performance. Government performance is surely in part determined by economic development, but it is also shaped by systematic variation in the histories of individual countries. This conclusion, we believe, is strongly supported by the data.

The results are more difficult to interpret as supporting a particular version of political or cultural theories of institutions. Taken as a whole, however, the re- 
The Journal of Law, Economics, \& Organization, V15 N1

sults support the political theories, since ethnolinguistic heterogeneity and legal origin remain extremely important factors shaping government performance, even controlling for religion. In addition to showing that history matters, we believe that we have provided some evidence that it is political history that matters most clearly. At the same time we would not interpret our evidence as outright rejecting the cultural theories of institutions.

Finally, we have consistently found that the better performing governments are larger and collect higher taxes. Poorly performing governments, in contrast, are smaller and collect fewer taxes. This result does not of course imply that it is often, or ever, socially desirable to expand a government of a given quality, but it tells us that identifying big government with bad government can be highly misleading. The question of how the better governments get to be bigger, or vice versa, remains open for future work.

\section{Appendix A}

Summary statistics

\begin{tabular}{|c|c|c|c|c|c|}
\hline Variable & $\begin{array}{l}\text { Number } \\
\text { of obs. }\end{array}$ & Mean & $\begin{array}{l}\text { Standard } \\
\text { Deviation }\end{array}$ & Minimum & Maximum \\
\hline \multicolumn{6}{|l|}{ Interference with private sector: } \\
\hline $\begin{array}{l}\text { Property rights index } \\
\text { Regulation index } \\
\text { Top marginal tax rate }\end{array}$ & $\begin{array}{r}149 \\
149 \\
82\end{array}$ & $\begin{array}{c}3.2752 \\
2.7047 \\
41.390\end{array}$ & $\begin{array}{r}1.1500 \\
0.9480 \\
12.2812\end{array}$ & $\begin{array}{l}1.0 \\
1.0 \\
0.0\end{array}$ & $\begin{array}{r}5.0 \\
5.0 \\
66.0\end{array}$ \\
\hline \multicolumn{6}{|l|}{ Efficiency: } \\
\hline $\begin{array}{l}\text { Corruption index } \\
\text { Bureaucratic delays } \\
\text { Tax compliance } \\
\text { Avg. government wages / } \\
\text { GNP per capita }\end{array}$ & $\begin{array}{r}126 \\
60 \\
49 \\
63\end{array}$ & $\begin{array}{l}5.6532 \\
4.6872 \\
3.1571 \\
1.9111\end{array}$ & $\begin{array}{l}2.2945 \\
1.4454 \\
1.0019 \\
1.2816\end{array}$ & $\begin{array}{l}0.1786 \\
2.0292 \\
1.43 \\
0.1\end{array}$ & $\begin{array}{l}10.0 \\
7.7760 \\
5.05 \\
7.1\end{array}$ \\
\hline \multicolumn{6}{|l|}{ Output of public goods: } \\
\hline $\begin{array}{l}\text { Log infant mortality } \\
\text { Log school achievement } \\
\text { Illiteracy rate } \\
\text { Infrastructure quality }\end{array}$ & $\begin{array}{r}196 \\
106 \\
128 \\
60\end{array}$ & $\begin{array}{r}3.7207 \\
1.3934 \\
31.0057 \\
5.5284\end{array}$ & $\begin{array}{r}0.9020 \\
0.5900 \\
22.5418 \\
1.8732\end{array}$ & $\begin{array}{l}1.9792 \\
0.1484 \\
1.8 \\
1.5\end{array}$ & $\begin{array}{c}5.2444 \\
2.4356 \\
81.3 \\
9.1521\end{array}$ \\
\hline \multicolumn{6}{|l|}{ Size of public sector: } \\
\hline $\begin{array}{l}\text { Transfers and subsidies as } \\
\% \text { of GDP }\end{array}$ & 90 & 9.1837 & 8.3419 & 0.1 & 37.2 \\
\hline $\begin{array}{l}\text { Government consumption as } \\
\% \text { of GDP }\end{array}$ & 104 & 15.028 & 4.9606 & 6.68 & 33.8 \\
\hline SOEs in the economy & 104 & 4.3654 & 2.2212 & 0.0 & 10.0 \\
\hline $\begin{array}{l}\text { Public sector employment as } \\
\% \text { of population }\end{array}$ & 124 & 4.3773 & 3.2256 & 0.4 & 17.3973 \\
\hline
\end{tabular}


Appendix A Continued

\begin{tabular}{|c|c|c|c|c|c|}
\hline Variable & $\begin{array}{l}\text { Number } \\
\text { of obs. }\end{array}$ & Mean & $\begin{array}{l}\text { Standard } \\
\text { Deviation }\end{array}$ & Minimum & Maximum \\
\hline \multicolumn{6}{|l|}{ Political freedom: } \\
\hline $\begin{array}{l}\text { Democracy index } \\
\text { Political rights index }\end{array}$ & $\begin{array}{l}161 \\
209\end{array}$ & $\begin{array}{l}3.6739 \\
4.6029\end{array}$ & $\begin{array}{l}3.8922 \\
2.2361\end{array}$ & $\begin{array}{l}0.0 \\
1.0\end{array}$ & $\begin{array}{r}10.0 \\
7.0\end{array}$ \\
\hline \multicolumn{6}{|l|}{ Determinants: } \\
\hline $\begin{array}{l}\text { Ethno-linguistic } \\
\text { fractionalization }\end{array}$ & 161 & 0.3264 & 0.3006 & 0.0 & 1.0 \\
\hline English legal origin & 212 & 0.3443 & 0.4763 & 0.0 & 1.0 \\
\hline Socialist legal origin & 212 & 0.1651 & 0.3721 & 0.0 & 1.0 \\
\hline French legal origin & 212 & 0.4339 & 0.4967 & 0.0 & 1.0 \\
\hline German legal origin & 212 & 0.0330 & 0.1791 & 0.0 & 1.0 \\
\hline Scandinavian legal origin & 212 & 0.0236 & 0.1521 & 0.0 & 1.0 \\
\hline $\begin{array}{l}\text { Protestant population as } \\
\% \text { of total }\end{array}$ & 206 & 14.6932 & 23.3400 & 0.0 & 99.8 \\
\hline $\begin{array}{l}\text { Roman Catholic population as } \\
\% \text { of total }\end{array}$ & 209 & 32.4077 & 36.1883 & 0.0 & 99.1 \\
\hline Muslim population as $\%$ of total & 209 & 21.7399 & 35.2773 & 0.0 & 99.9 \\
\hline Other populations as $\%$ of total & 206 & 30.9192 & 31.8005 & 0.0 & 100.0 \\
\hline \multicolumn{6}{|l|}{ Economic Development: } \\
\hline Latitude & 209 & 0.2810 & 0.1885 & 0.0 & 0.8 \\
\hline Log GNP per capita & 186 & 7.2858 & 1.3572 & 4.6471 & 10.1517 \\
\hline
\end{tabular}




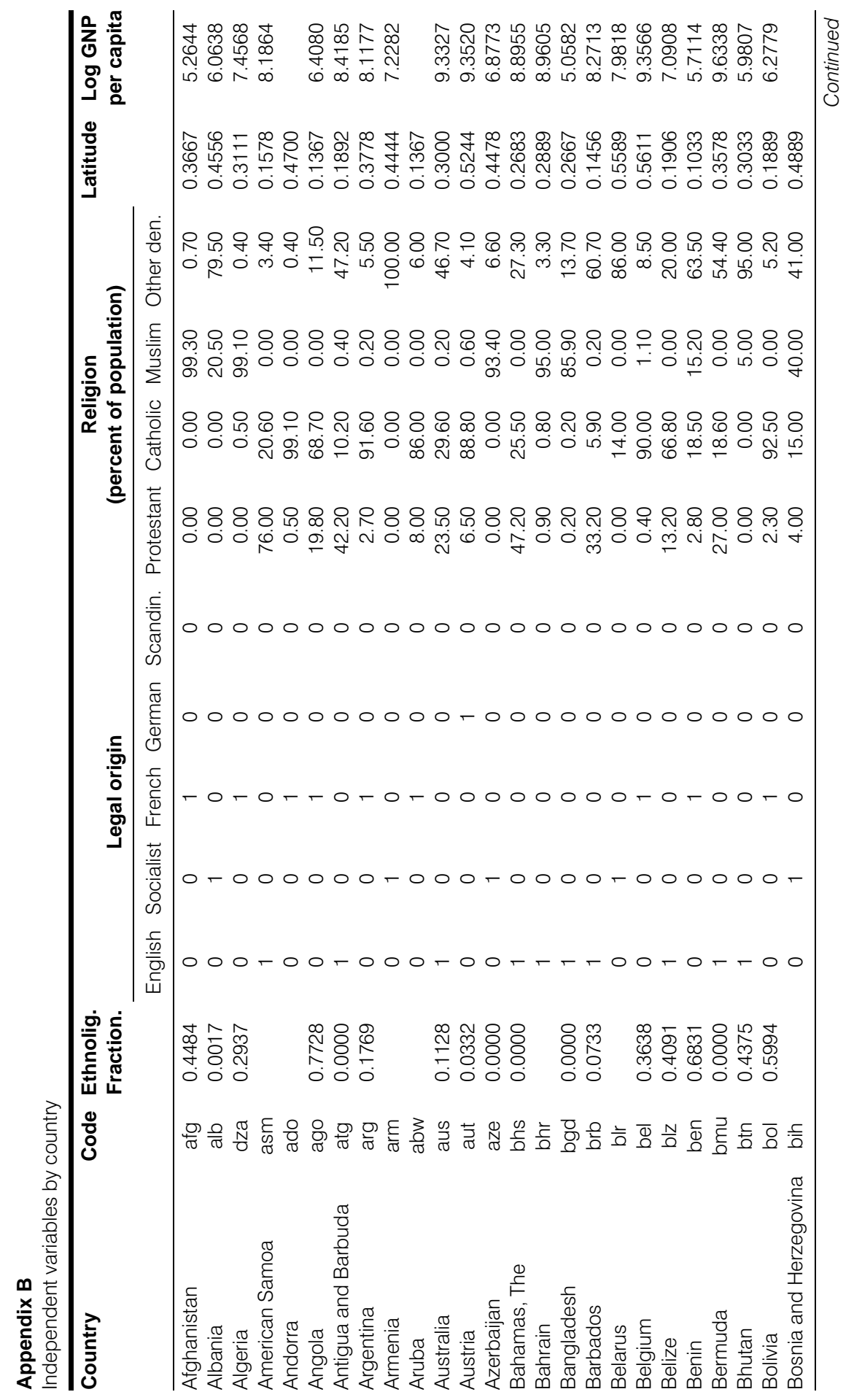




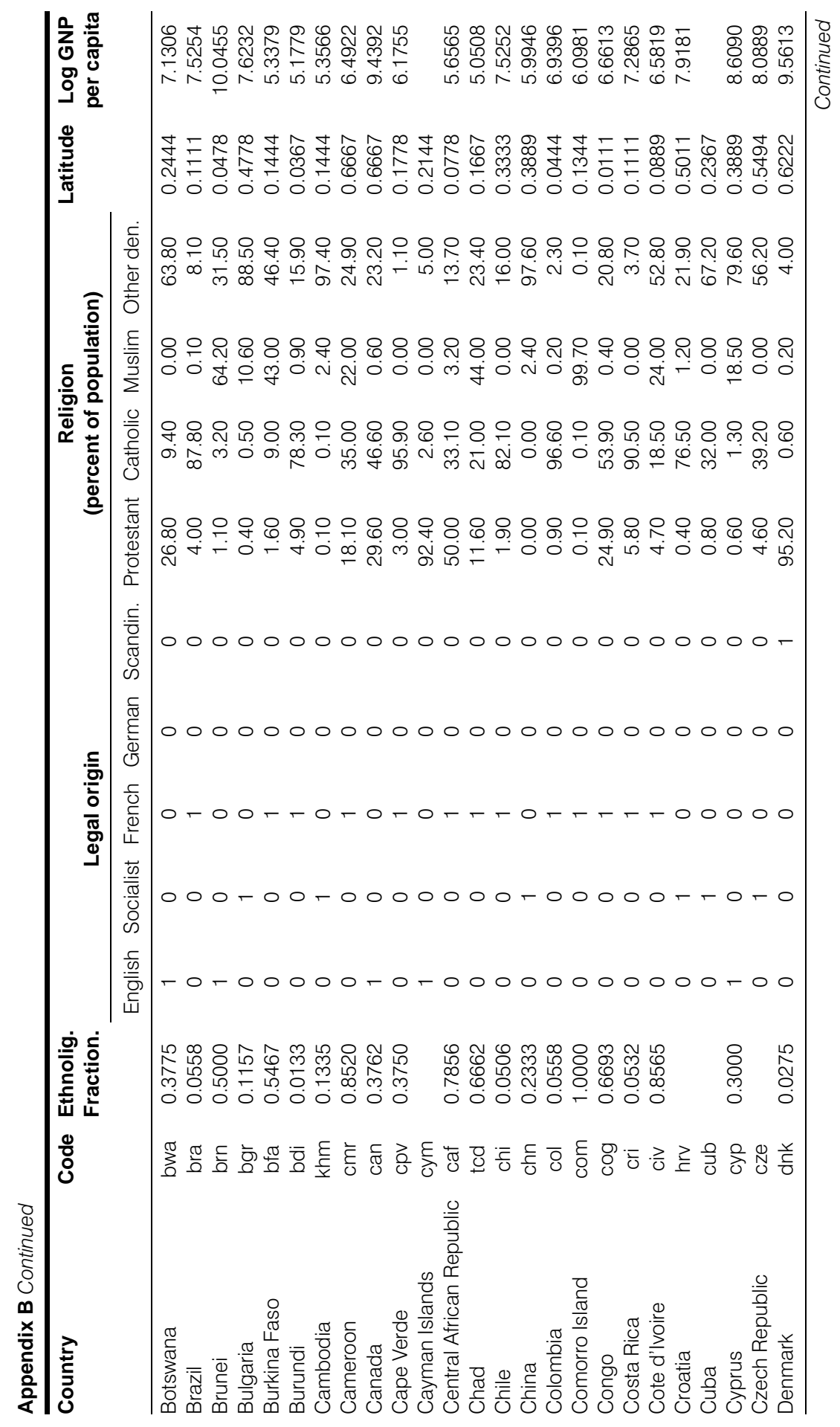




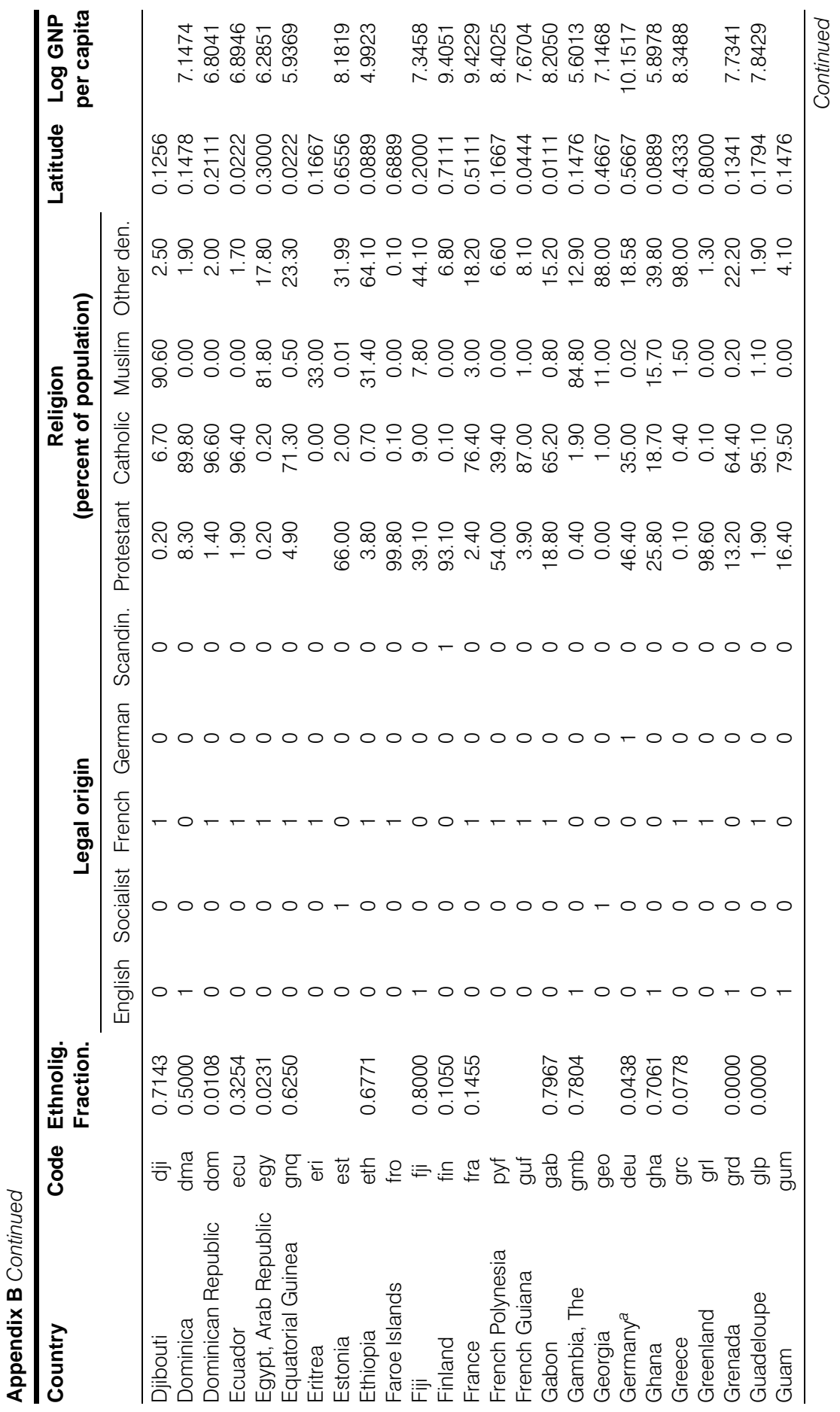




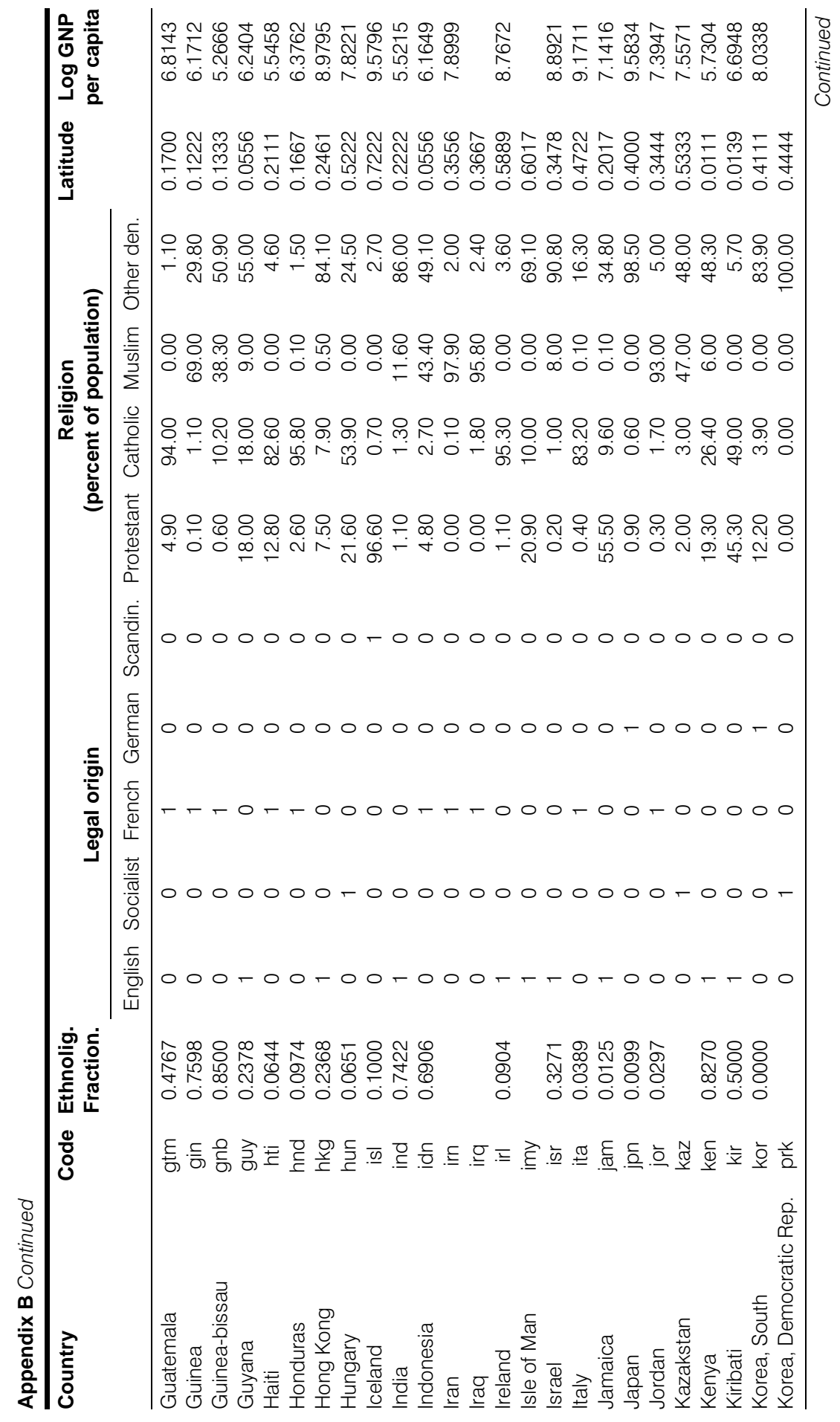




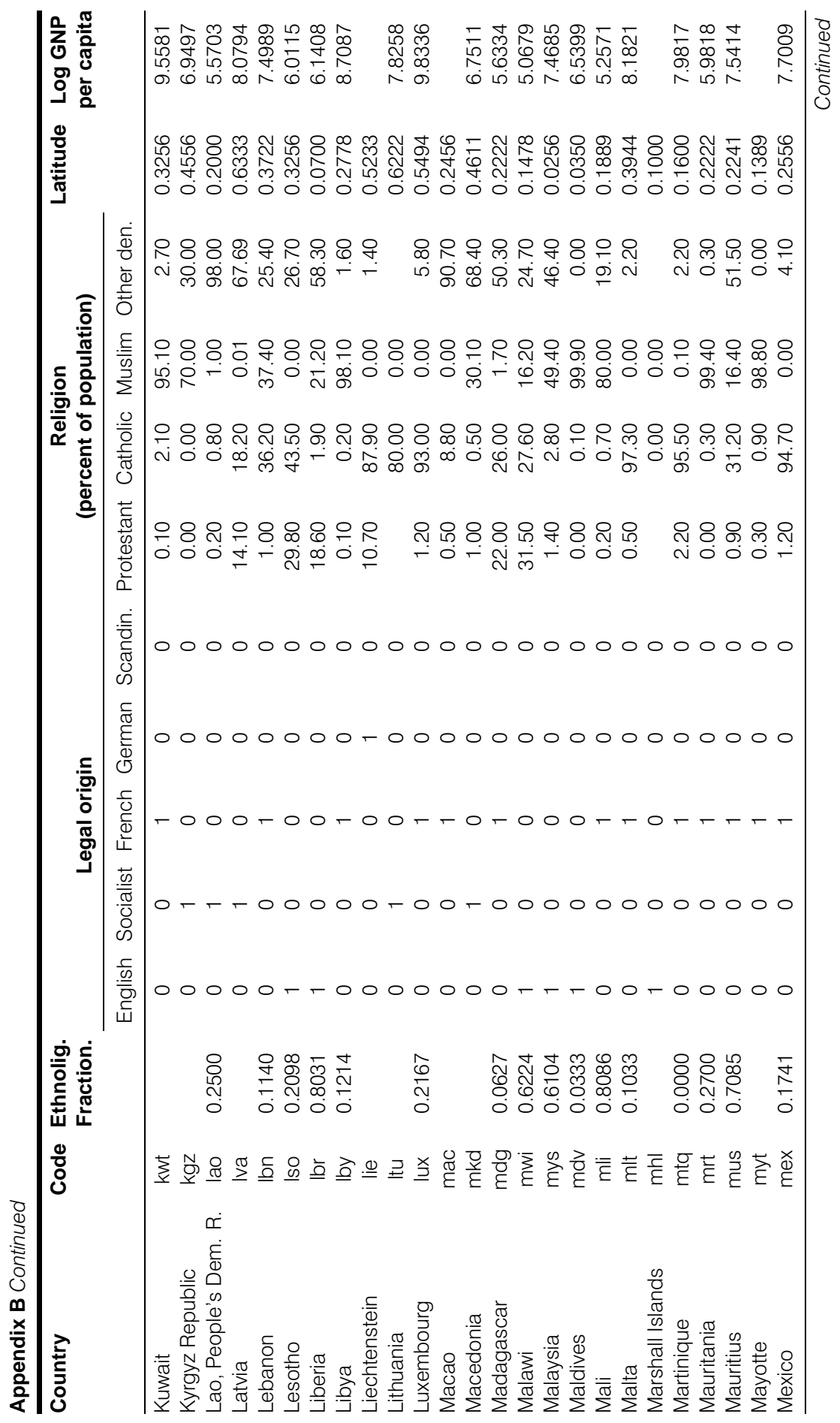




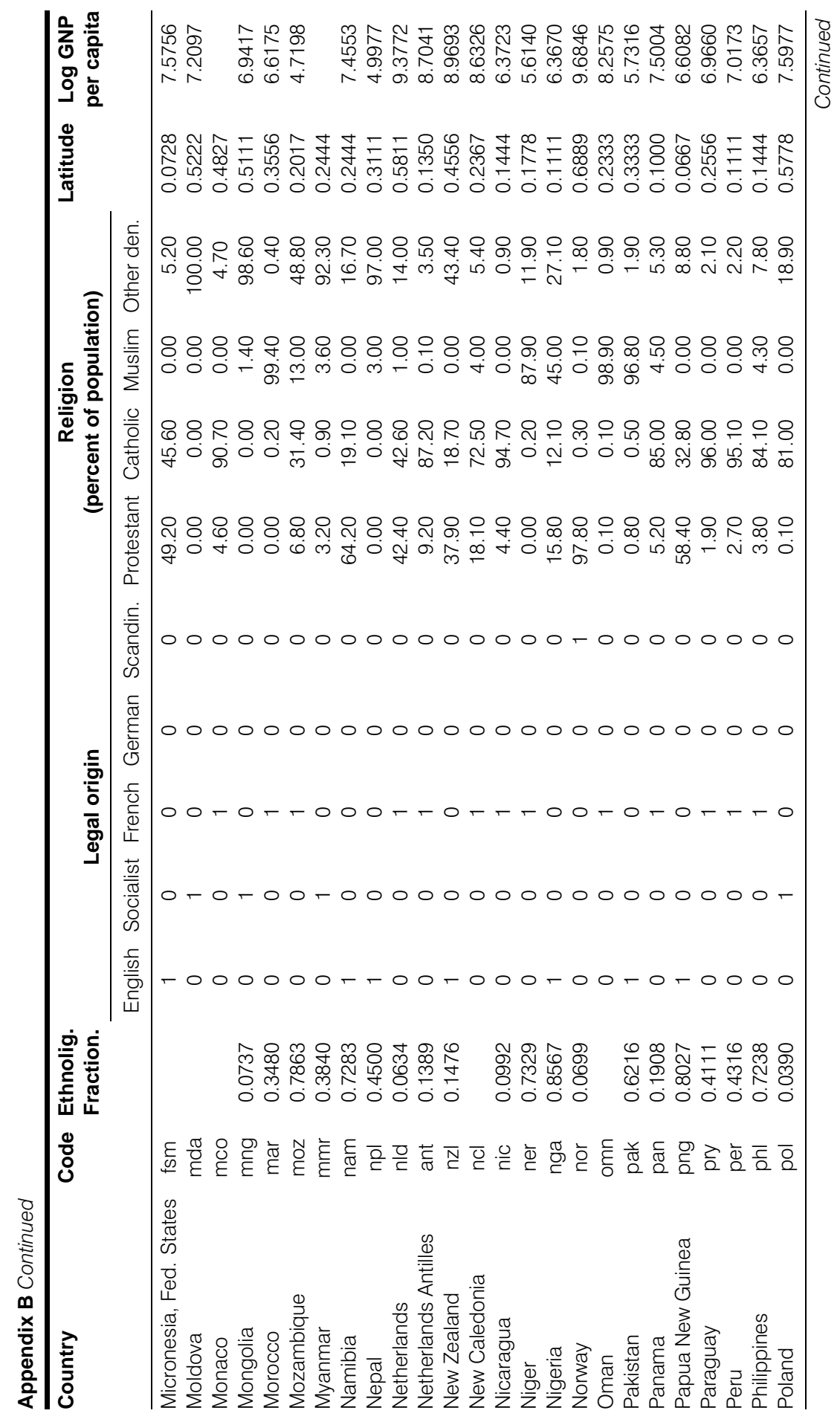




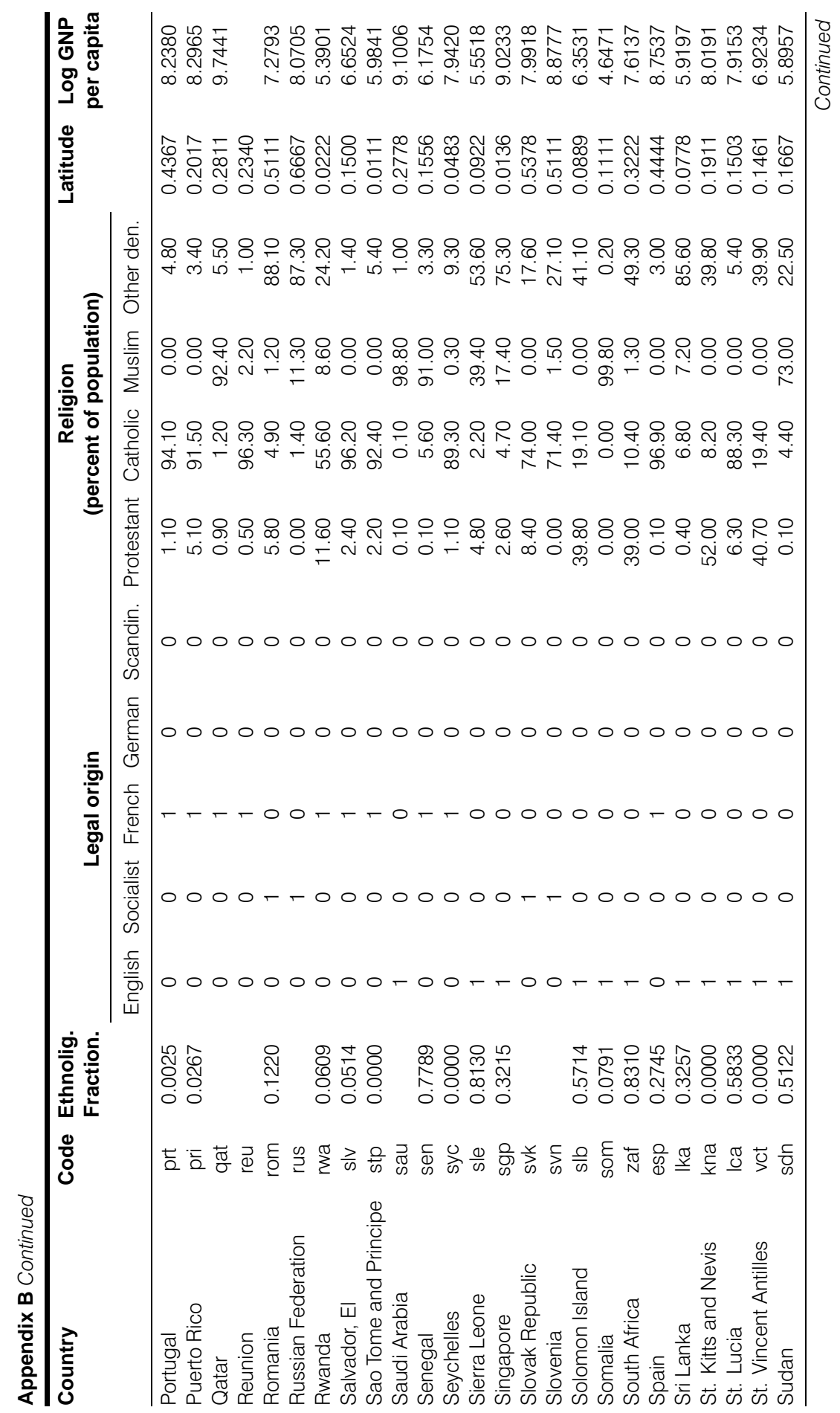




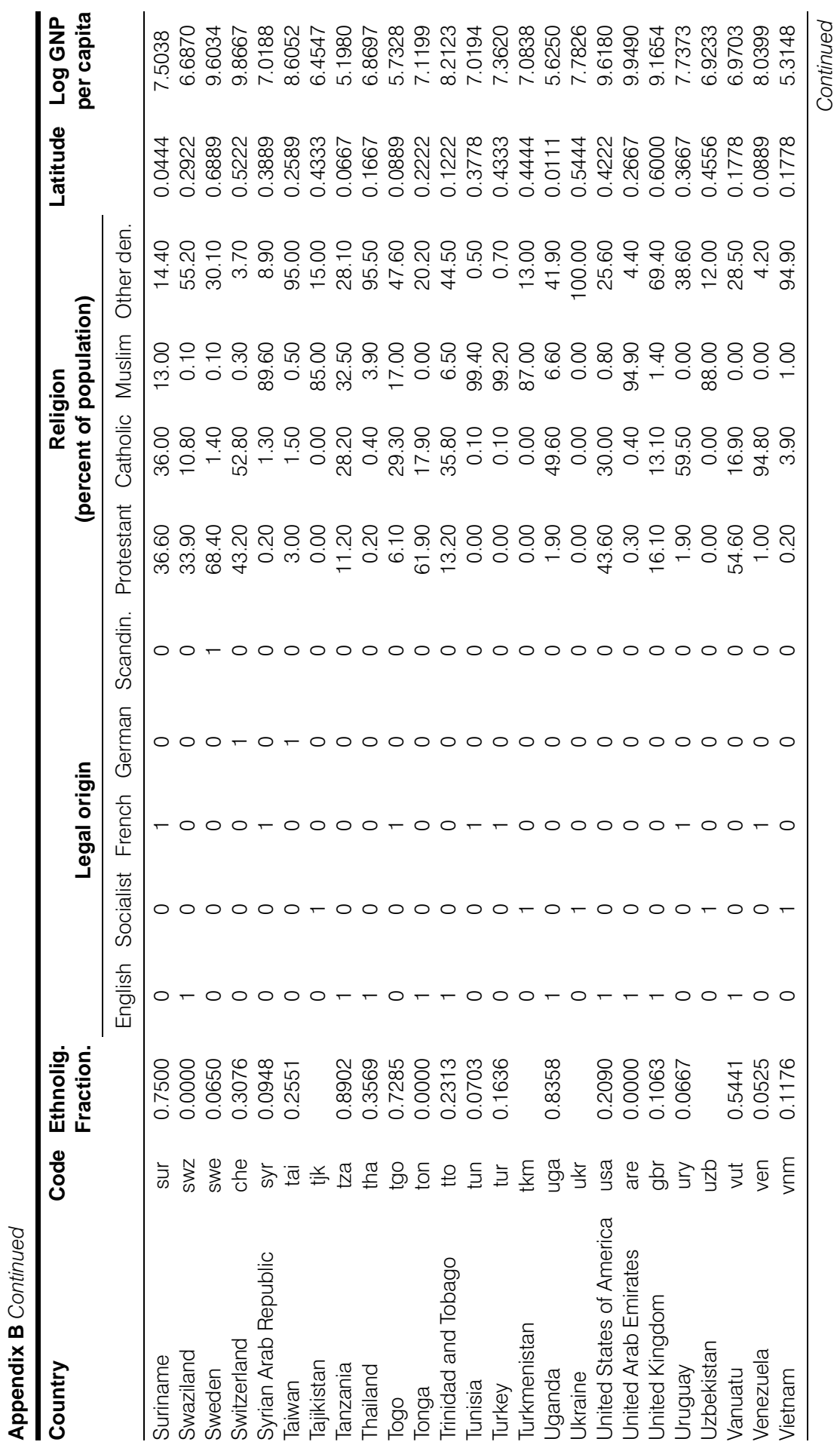


276 The Journal of Law, Economics, \& Organization, V15 N1

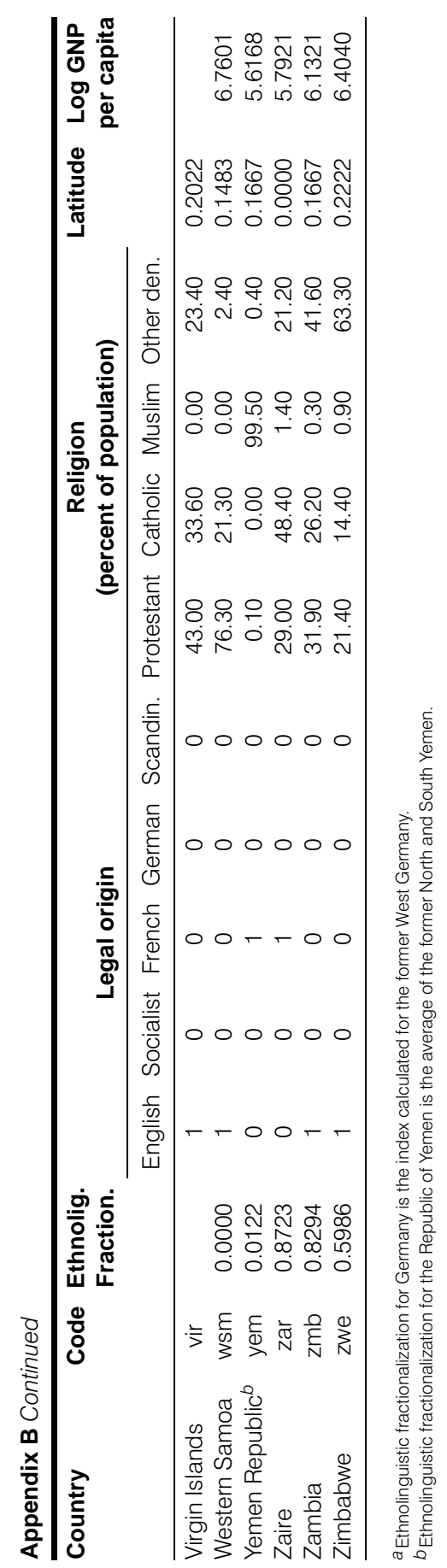




\section{References}

Alesina, Alberto, Reza Baqir, and William Easterly. 1999. "Public Goods and Ethnic Divisions," 114 Quarterly Journal of Economics.

Banfield, Edward. 1958. The Moral Basis of a Backward Society. New York: Free Press. Barraclough, Geoffrey. 1972. The Medieval Papacy. New York: Harcourt, Brace and World.

Barrett, David B., ed. 1982. World Christian Encyclopedia: A Comparative Study of Churches and Religions in the Modern World, AD 1900-2000. New York: Oxford University Press.

Barro, Robert. 1991. "Economic Growth in a Cross-Section of Countries," 106 Quarterly Journal of Economics 407-443.

. 1996a. "Democracy and Growth," 1 Journal of Economic Growth 1-27.

1996b. "Determinants of Economic Growth: A Cross-Country Empirical Study," Working Paper Series 5698, National Bureau of Economic Research.

and Jong-Wha Lee. 1994. Unpublished dataset for a panel of 138 countries. Harvard University.

Bates, Robert. 1981. Markets and States in Tropical Africa. Berkeley: University of California Press.

Beasley, William. 1972. The Meiji Restoration. Palo Alto, CA: Stanford University Press.

Becker, Gary. 1983. "A Theory of Competition Among Pressure Groups for Political Influence," 98 Quarterly Journal of Economics 371-400.

Boycko, Maxim, Andrei Shleifer, and Robert W. Vishny. 1995. Privatizing Russia. Cambridge: MIT Press.

1996. "A Theory of Privatization," 106 Economic Journal 309-319.

Brewer, John. 1988. The Sinews of Power. New York: Knopf.

Bruk, S. I., and V. S. Apenchenko, eds. in chief. 1964. Atlas Narodov Mira. Moscow: MiklukhoMaklai Ethnological Institute at the Department of Geodesy and Cartography of the State Geological Committee of the Soviet Union, USSR Academy of Sciences.

BERI (Business Environmental Risk Intelligence), Center for Institutional Reform and the Informal Sector (IRIS). 1995. BERI's Operations Risk Index. College Park: IRIS, University of Maryland. Central Intelligence Agency. 1996. CIA World Factbook (published online).

Coleman, James. 1990. Foundations of Social Theory. Cambridge: Harvard University Press.

David, René, and John Brierley. 1978. Major Legal Systems in the World Today. New York: Free Press.

DeLong, Bradford, and Andrei Shleifer. 1993. "Princes and Merchants: Government and City Growth Before the Industrial Revolution," 36 Journal of Law and Economics 671-702.

Demsetz, Harold. 1967. "Toward a Theory of Property Rights," 57 American Economic Review Papers and Proceedings 347-359.

De Toqueville, Alexis. [1858] 1955. The Old Regime and the French Revolution. New York: Doubleday.

Easterly, William, and Ross Levine. 1997. "Africa's Growth Tragedy: Policies and Ethnic Divisions," 112 Quarterly Journal of Economics 1203-1250.

Elster, Jon, Claus Offe, and Ulrich Press. 1998. Institutional Design in Post-Communist Societies. Cambridge: Cambridge University Press.

Ertman, Thomas. 1997. Birth of the Leviathan. Cambridge: Cambridge University Press.

Finer, Samuel. 1997. The History of Government, Vol. I-III. Cambridge: Cambridge University Press.

Freedom House. 1996. World Survey of Economic Freedom 1995-1996: A Freedom House Study. New Brunswick, NJ: Transaction Publishers.

1996. Freedom in the World: The Annual Survey of Political Rights and Civil Liberties 1995-1996. New Brunswick, NJ: Freedom House.

Fukuyama, Francis. 1995. Trust. New York: Free Press.

Grossman, Sanford, and Oliver Hart. 1986. "The Costs and Benefits of Ownership: a Theory of Vertical and Lateral Integration," 94 Journal of Political Economy 691-719.

Gunnemark, Erik V. 1991. Countries, Peoples, and Their Languages: The Linguistic Handbook. Gothenburg, Sweden: Lanstryckeriet.

Gwartney, James, Robert Lawson, and Walter Block. 1996. Economic Freedom of the World, 
1975-1995. Vancouver: The Fraser Institute.

Hall, Robert, and Charles Jones. 1999. "Fundamental Determinants of Output per Worker Across Countries," forthcoming in Quarterly Journal of Economics.

Hayek, Friedrich. 1944. The Road to Serfdom. London: G. Routledge and Sons.

Holmes, Kim R., Bryan T. Johnson, and Melanie Kirkpatrick. 1997. 1997 Index of Economic Freedom. Washington, D.C.: The Heritage Foundation.

Huntington, Samuel. 1968. Political Order in Changing Societies. New Haven: Yale University Press.

1991. The Third Wave. Norman: University of Oklahoma Press.

Jaggers, Keith, and Ted Robert Gurr. 1996. Polity III: Regime Change and Political Authority, 1800-1994 [computer file]. Ann Arbor: Inter-university Consortium for Political and Social Research [distributor].

Johnson, Simon, Daniel Kaufmann, and Andrei Shleifer. 1997. "The Unofficial Economy in Transition," 2 Brookings Papers on Economic Activity 159-240.

Johnson, Stuart. 1975. Frederick the Great and His Officials. New Haven: Yale University Press. Jones, Eric. 1981. The European Miracle. Cambridge: Cambridge University Press.

Kamen, Henry. 1997. The Spanish Inquisition. New Haven: Yale University Press.

Knack, Stephen, and Philip Keefer. 1995. "Institutions and Economic Performance: Cross-country Tests Using Alternative Institutional Measures," 7 Economics and Politics 207-227.

1997. "Does Social Capital Have an Economic Payoff? A Cross-country Investigation,"

112 Quarterly Journal of Economics 1251-1288.

Landes, David. 1998. The Wealth and Poverty of Nations. New York: W. W. Norton.

La Porta, Rafael, Florencio Lopez-de-Silanes, Andrei Shleifer, and Robert W. Vishny. (1997a).

"Legal Determinants of External Finance," 52 Journal of Finance 1131-1150.

(1997b). "Trust in Large Organizations," 87 American Economic Review Papers and

Proceedings 333-338.

1998. "Law and Finance," 106 Journal of Political Economy 1113-1155.

Lindbeck, Assar. 1997. “The Swedish Experiment,” 35 Journal of Economic Literature 1273-1319.

Mack Smith, Denis. 1997. Modern Italy: a Political History. Ann Arbor: University of Michigan Press.

Marx, Karl. 1974 [1872]. Das Kapital. London: Lawrence and Wishart.

Mauro, Paolo. 1995. "Corruption and Growth," 110 Quarterly Journal of Economics 681-712.

Montesquieu, Charles de Secondat. 1748. The Spirit of the Laws. Paris.

Muller, Siegfried H. 1964. The World's Living Languages: Basic Facts of Their Structure, Kinship, Location, and Number of Speakers. New York: Ungar.

North, Douglass. 1981. Growth and Structural Change. New York: W. W. Norton. 1990. Institutions, Institutional Change, and Economic Performance. Cambridge: Cambridge University Press.

Olson, Mancur. 1965. The Logic of Collective Action. Cambridge: Harvard University Press. 1982. The Rise and Decline of Nations. New Haven: Yale University Press.

.1993. "Dictatorship, Democracy, and Development," 87 American Political Science Review $567-576$.

1996. "Big Bills Left on the Sidewalk: Why Some Nations are Rich, and Others Poor," 10 Journal of Economic Perspectives 3-24.

Pipes, Richard. 1974. Russia under the Old Regime. New York: Charles Scribner's Sons.

Political Risk Services. International Country Risk Guide. East Syracuse, NY: Political Risk

Services, Institutional Reform and Informational Sector, various years.

Putnam, Robert. 1993. Making Democracy Work: Civic Traditions in Modern Italy. Princeton: Princeton University Press.

Rauch, James. 1995. "Bureaucracy, Infrastructure, and Economic Growth: Evidence from U.S. Cities During the Progressive Era," 85 American Economic Review 968-979.

and Peter Evans. 1997. "Bureaucratic Structure and Bureaucratic Performance in Less Developed Countries," mimeo, University of California, San Diego.

Roberts, Janet. 1962. "Sociocultural Change and Communication Problems," in Frank A. Rice, ed., Study of the Role of Second Languages in Asia, Africa, and Latin America. Washington, D.C.: 
Center for Applied Linguistics of the Modern Language Association of America, 105-123.

Schiavo-Campo, Salvatore, Giulio de Tommaso, and Amitabha Mukherjee. 1997. "An International Statistical Survey of Government Employment and Wages," in Government Employment and Pay: A Global and Regional Perspective Series, Public Sector Management and Information Technology Team, Technical Department for Europe, Central Asia, Middle East and North Africa, World Bank.

Shleifer, Andrei, and Robert W. Vishny. 1993. "Corruption,” 108 Quarterly Journal of Economics 599-617.

1994. "Politicians and Firms," 109 Quarterly Journal of Economics 995-1025.

1998. The Grabbing Hand: Government Pathologies and their Cures. Cambridge: Harvard University Press.

Smith, Adam. 1976, [1776]. An Inquiry into the Nature and Causes of the Wealth of Nations. Chicago: University of Chicago Press.

Statistical Abstract of the World. 1995. New York: Gale Research, Inc.

Tilly, Charles. 1990. Coercion, Capital, and European States. Berkeley: University of California Press.

Treisman, Daniel. 1997. "The Causes of Corruption: a Cross-National Study," mimeo, UCLA.

United Nations. 1995. Demographic Yearbook. New York: Department of Economic and Social Affairs, Statistical Office, United Nations.

Weber, Max. 1958. The Protestant Ethic and the Spirit of Capitalism. New York: Charles Scribner's Sons.

Weingast, Barry. 1995. "The Economic Role of Political Institutions: Market-Preserving Federalism and Economic Development," 11 Journal of Law, Economics \& Organization 131.

World Bank. 1995. Bureaucrats in Business. Oxford: Oxford University Press. 1997. World Development Indicators 1997 [CD-ROM]. Washington, D.C.: World Bank.

World Economic Forum. 1996. The Global Competitiveness Report 1996. Geneva: World Economic Forum.

Worldmark Encyclopedia of the Nations, $8^{\text {th }}$ ed. 1995. Detroit: Gale Research. 